Sarah J. Pethybridge and Frank S. Hay

Tasmanian Institute of Agricultural Research (TIAR), University of Tasmania, Burnie, Tasmania, Australia

Dez J. Barbara

Warwick HRI, University of Warwick, Wellesbourne, Warwick, United Kingdom

Kenneth C. Eastwell

Washington State University, Irrigated Agriculture Research and Extension Center, Prosser, WA, USA

Calum R. Wilson

TIAR - University of Tasmania, New Town Research Laboratories, New Town, Tasmania, Australia

\title{
Viruses and Viroids Infecting Hop: Significance, Epidemiology, and Management
}

The hop (Humulus lupulus) is a hardy, climbing, dioecious, perennial plant native to Europe, Asia, and North America (172). The genus Humulus belongs to the family Cannabaceae and contains three species: $H$. japonicus, $H$. lupulus, and $H$. yunnanensis $(32,117)$. Hops are grown predominantly for their cones (strobiles), which contain glands producing resins, essential oils, and polyphenols (Fig. 1). These compounds are used primarily to add bitterness and aroma to beer. The most important of these compounds for brewing are the alpha acids. Alpha acids are acylsubstituted phloroglucinols, differing from each other only in the nature of the acyl $R$ side chain. They can be separated into humulone $(\mathrm{R}=$ isovaleryl), cohumulone $(\mathrm{R}$ $=$ isobutryl $)$, adhumulone $(\mathrm{R}=$ alphamethyl butryl), prehumulone, and posthumulone (127). The main properties of alpha acids in relation to beer production are improved foam stability, suppression of gushing, and contributions to bacteriological stability (48). The bitterness of beer is related to stereoisomer formation of each major alpha acid in the brewing process (124). Beta acids are predominantly separated into lupulone, colupulone, and adlupulone. They have limited bittering power but are particularly important because of their bactericidal properties (194). More than 200 other essential oils also occur within the cones, including hydrocarbons and oxygenated and sulfur-containing compounds, which are responsible for the

Corresponding author: Sarah J. Pethybridge, Tasmanian Institute of Agricultural Research (TIAR), University of Tasmania, P.O. Box 3523, Burnie, Tasmania, 7320, Australia; E-mail: sarah_jp@utas.edu.au

doi:10.1094/PDIS-92-3-0324

(C) 2008 The American Phytopathological Society aroma and flavor of the final product (170). Hops are also grown for their medicinal and soporific effects, as ornamental plants, and as edible delicacies (146).

The areas in which hop can be grown are limited by strict day length and temperature requirements for flowering and hence cone production. Production is generally restricted around $35^{\circ}$ latitudes in both hemispheres $(32,117)$. Supplementary artificial lighting has been used to produce hops in areas of lower latitudes, such as in South Africa (196). In 2005, the most significant regions of hop production (i.e., countries with $>1,000$ ha) were Germany, the Czech Republic, Poland, Slovenia, Ukraine, the United Kingdom, the northwestern states of the United States (Idaho, Washington, and Oregon), and China. Lesser quantities were grown in 14 other European countries. A few other countries grow 500 ha or less, most notably Japan, Argentina, Australia, South Africa, New Zealand, and India (26). The largest area of production was in Germany $(17,161$ ha producing $34,466.8$ metric tons), while 11,956 ha were grown in the United States, producing 24,002 metric tons (26).

Viruses and viroids pose significant constraints to the production of high yields of hop cultivars worldwide. In some countries, such as Australia and New Zealand, these pathogens are considered the only significant pathological problems. This is due to the absence of severe fungal diseases, such as powdery mildew (154) and downy mildew (155). Infections by five viruses and two viroids are or have been widespread and important in commercial hop yards. A further 12 viruses (of which two are poorly characterized) and 1 viroid have been reported in hop; these either have limited distributions or occur only sporadically and are not considered important. The viruses considered generally important are the three carlaviruses, Hop mosaic virus (HpMV) $(3,20,94,156)$, Hop latent virus (HpLV) $(4,21,55,150,180)$, and American hop latent virus (AHLV) $(5,22,149)$; the ilarvirus Apple mosaic virus (ApMV) $(27,28,46,64)$; and the nepovirus Arabis mosaic virus (ArMV) $(6,9,50,82)$. The important viroids infecting hops are Hop latent viroid (HpLVd) $(10,14,24,25,151)$ and Hop stunt viroid (HpSVd) (162-164,201).

Although the problems posed by viruses and viroids for the production of hops are not unique among perennial crops, they are particularly challenging because the rates of spread are often much higher than in other crops such as top fruit. As such, the control measures used with hops present a good case study for the control of these pathogens in crops where long life (hop yards are typically kept for up to 20 years and may last 50 years) means they are repeatedly exposed to infection. The reasons for rapid spread relative to tree fruit crops are unclear, but one might speculate that the very rapid and massive annual growth (the entire aboveground part of the plants is replaced every year, and main stems generally grow more than 5 meters in only 3 to 4 months) in closely spaced plantings favors both mechanical transmission (for HpSVd, HpLVd, and ApMV) and heavy infestations with aphids (for the carlaviruses). The study of hop viruses and viroids also emphasizes the need to fully understand and quantify the effects of these pathogens on yield and/or quality of crops, which are highly dependent on cultivar, pathogen strain, and environmental conditions.

\section{Carlaviruses}

HpMV. Hop mosaic disease was first described by Salmon (156), although characteristic symptoms of this disease were recorded as early as 1907 in experimental plots in the United Kingdom (94). HpMV 
has since been found infecting hops in commercial hop yards throughout Europe $(144,167)$, Australia (140), the United States (83), New Zealand (76), China (202), Japan (79), and South Africa (196).

Virions of HpMV are filamentous with modal dimensions of $651 \mathrm{~nm}$ by $13.8 \mathrm{~nm}$ $(3,20)$. The genome is estimated to consist of ca. 8,800 nucleotides and is encapsulated by a single protein species of molecular mass ca. $34.1 \mathrm{kDa}(3,70)$.

HpMV is commonly found only in $H$. lupulus $(3,4)$ but has also been detected in wild plants of Urtica urens in the United Kingdom (3), and in Stellaria media, Chenopodium album, Plantago major, and Polygonum aviculare in Germany (20). The significance of these wild hosts is uncertain, but they are thought unlikely to be important for the disease in hops. Infection by HpMV of most modern hop cultivars is generally symptomless, but the effect on hop growth or yield varies in magnitude $(140,182)$. However, in the no longer commonly grown mosaic-sensitive Goldings-type cultivars (i.e., Bramling, Eastwell Golding, Wye Mathon, and J78) HpMV may result in marked symptoms and may be lethal. Leaves of infected mosaic-sensitive plants develop a conspicuous clearing or yellow banding along main veins and curl downward at the margin. Vein clearing is a better diagnostic feature, as the mottle symptom is similar to that induced by some nutrient deficiencies or herbicides (Fig. 2). Infected plants are often stunted, bines tend to fall away from the support string, and plants produce only a small number of cones (182). Some contemporary cultivars with Goldings heritage, such as cv. Chinook, exhibit moderate yield losses and symptom development (147). Different strains of HpMV have been suggested but not fully described $(55,92,94)$.

HpLV. This virus was first described by Schmidt et al. (168) but was thought to be synonymous with HpMV (29) until a latent infection was discovered in a cultivar highly sensitive to HpMV infection $(148,150,187)$. HpLV has been reported in hop yards throughout Europe $(54,180)$, the United States (150), New Zealand (76), Australia (112,140), China (202), South Africa (196), and Japan (79). HpLV has only been found in $H$. lupulus $(4,21)$, with most cultivars remaining symptomless, although sporadic development of systemic chlorotic flecking in cv. Hersbrucker Spät has been described (54).

Virions of $\mathrm{HpLV}$ are filamentous with characteristic dimensions slightly larger than HpMV of $674 \mathrm{~nm}$ by $14.4 \mathrm{~nm}$. The predicted molecular mass of the capsid protein is $33 \mathrm{kDa}$, and the genome consists of ca. 8,612 nucleotides in one singlestranded RNA species $(4,21,72)$.

AHLV. AHLV is common in the United States but generally occurs at a lower frequency than other carlaviruses (149).
AHLV was reported at low incidence in New Zealand (76). It has been reported in post-entry quarantine of breeding material in Germany (57), the United Kingdom (4), and Australia (112) with infected plants destroyed and the virus eradicated (22). Virions are filamentous particles with modal dimensions of $678 \mathrm{~nm}$ by $15 \mathrm{~nm}$. The

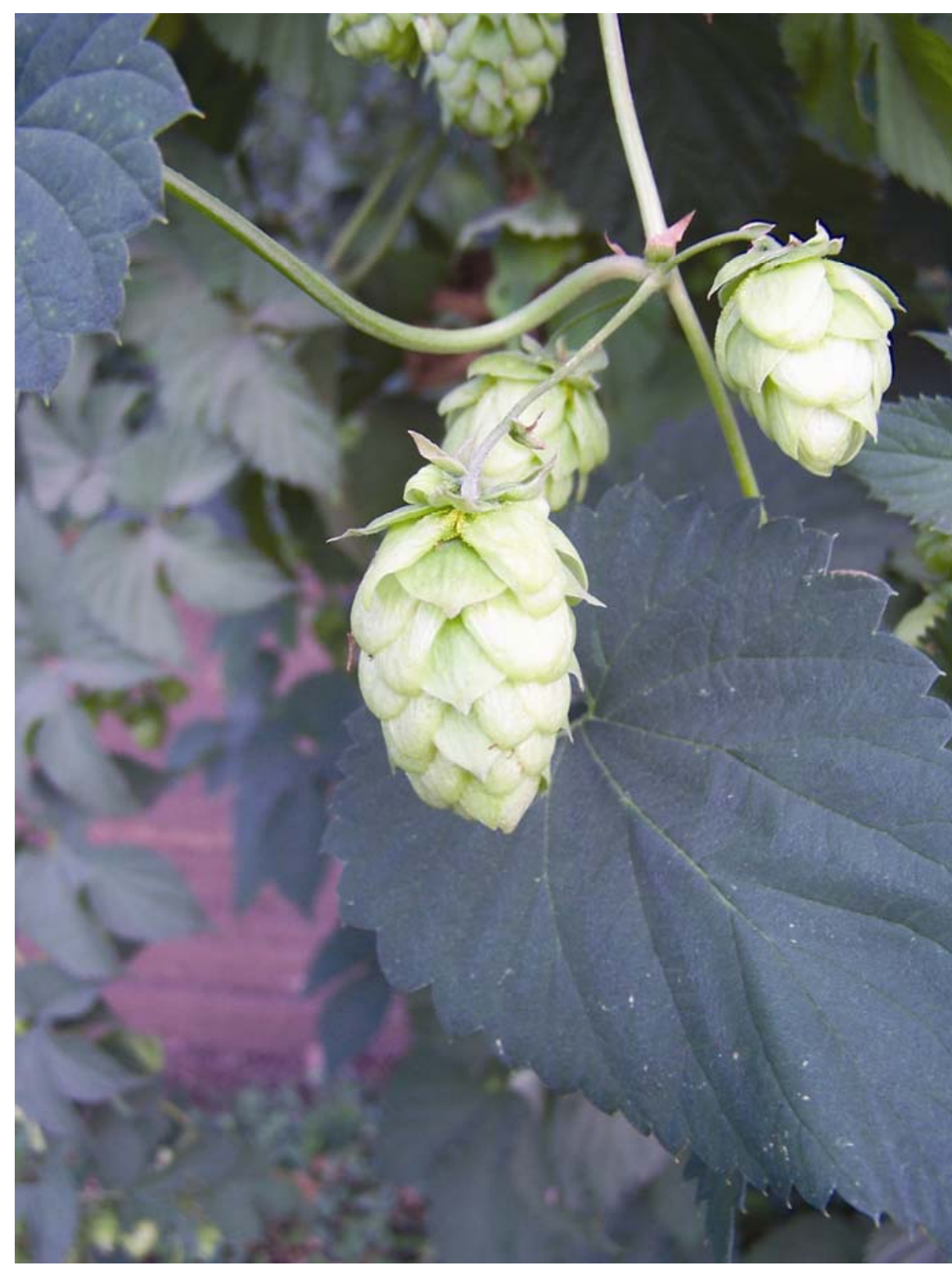

Fig. 1. Hop cones (strobiles) contain glands producing resins, essential oils, and polyphenols. (Courtesy D. H. Gent)

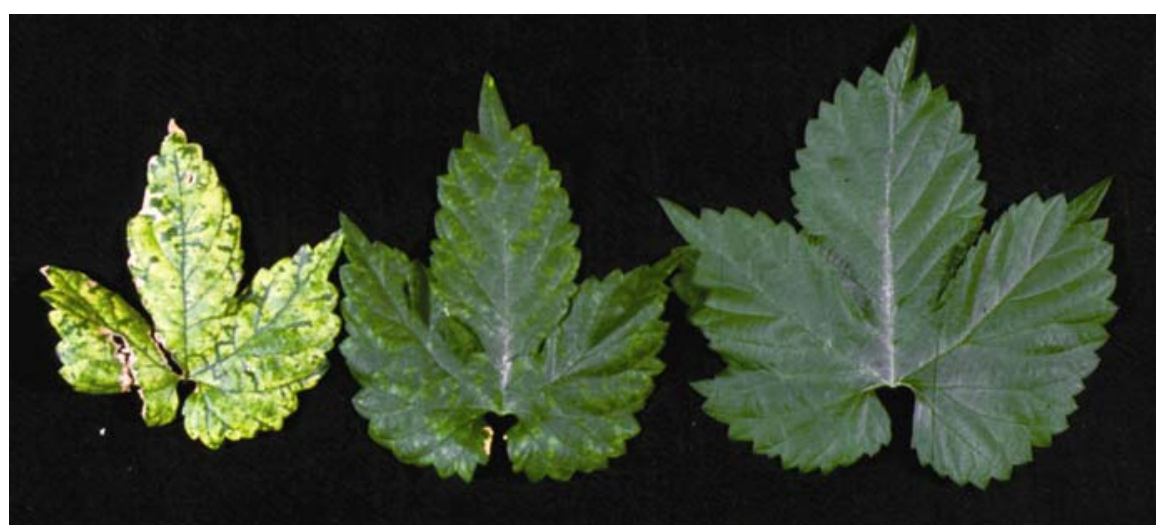

Fig. 2. Range of symptoms (mild on right and severe on left) on leaves from infection by Hop mosaic virus on a sensitive Golding-type hop cultivar. 
genome of this virus consists of ca. 8,605 nucleotides with a capsid protein of 34.5 $\mathrm{kDa}$ (22). AHLV shares little serological relationship to $\mathrm{HpLV}, \mathrm{HpMV}$, or other carlaviruses (22). AHLV has only been found in $H$. lupulus $(4,5,22)$.

Transmission of hop carlaviruses. The hop carlaviruses are principally spread between hop plants by aphid vectors in a nonpersistent manner and by mechanical means $(4,58,91)$. Transmission by seed is not considered important for HpLV (4) or HpMV (20). There are no reports of seed transmission of AHLV.

The most important aphid vector for the three hop carlaviruses in most production regions is the hop-damson aphid, Phorodon humuli, $(3,58,125,126)$ due to its high abundance. $P$. humuli is a holocyclic aphid that overwinters on Prunus spp. as an egg. Besides acting as a virus vector, it also causes direct damage from feeding on cones and leaves over summer (58). Migration from Prunus spp. to hop by the alate form begins generally in early May but depends upon daily temperatures, after which apterous forms are produced on hop (58). The polyphagous potato aphid (Macrosiphum euphorbiae) and green peach aphid (Myzus persicae) both vector HpMV and HpLV $(3,4,47)$. These additional species are likely to be important in establishing new foci, especially in Australian and New Zealand hop yards where the hopdamson aphid is not present $(76,113,139)$. Studies with the oat aphid (Sitobion avenae) failed to transmit HpMV (3). Several other aphid species have been recorded within hop yards $(56,134)$. As most viruses transmitted nonpersistently by aphids have multiple vectors, it is possible that a much wider range of aphids and perhaps transient visitors also play a role in hop carlavirus transmission $(133,134)$.

Spatial patterns of carlavirus epidemics. Rapid spread of HpMV and HpLV in commercial yards occurs where $P$. humuli is endemic. In the United Kingdom, in a block of initially virus-tested (no infections detected) cv. Northern Brewer, HpMV was found in ca. 50\% of plants after 1 year (182). In another plot, Adams et al. (7) reported that $42 \%$ of plants were infected after 1 year, and that in the second year, $81 \%$ of plants were infected. Adams et al. (8) further reported $87 \%$ of plants were infected by HpLV and HpMV 3 years after planting with virus-tested material. In the United States, the incidence of HpLV, HpMV, and AHLV in cv. Horizon and cv. Nugget yards 3 years of age was 66, 25, and $34 \%$, respectively (135). Rapid spread after planting with virus-tested material was anticipated from the presence of $P$. humuli (35), but the incidence of HpLV and HpMV in these yards was considerably lower than that of HpLV and HpMV in the United Kingdom and Europe (135).

In comparison with observations in Europe and the United States, carlavirus spread in Australian and New Zealand hop yards is relatively slow. This can be attributed to the absence of $P$. humuli $(76,113,139,140)$. In Australia, the incidence of these viruses after yard establishment with virus-tested material is dependent upon cultivar $(139,140)$. For example, in yards of the virus-susceptible cv. Victoria, 89 to $98 \%$ and 72 to $96 \%$ of plants were infected with HpLV and HpMV, respectively, after 7 and 9 years. In contrast, in yards of the relatively resistant cv. Pride of Ringwood of at least 10 years of age, HpLV and HpMV infections were not frequently detected (140).

In areas where $P$. humuli is ubiquitous, strong edge effects and infection gradients are characteristic of carlavirus spread, reflecting the role of Prunus spp., such as sloe $(P$. spinosa), plum ( $P$. domestica), cherry plum ( $P$. cerasifera), and damson $(P$. insititia) as winter hosts of the vector (34). Obstacles such as roads, headlands, or hedgerows have been shown to significantly steepen the infection gradient (8). Chambers et al. (38) reported carlavirus incidence as almost $100 \%$ in the outer rows of a cv. Perle yard positioned directly adjacent to a hedgerow and infected block, while virus incidence in inner rows was less than $10 \%$. Infection was reduced significantly in plots of cv. Wye Northdown with guard rows of cv. Northern Brewer to reduce aphid flight incursions.

Spatial and temporal analyses of carlavirus epidemics in Australia have consistently shown aggregation of infected plants along rows with lesser, but significant, aggregation across rows. This has strongly suggested the role of mechanical transmission through agronomic activities such as mowing of basal growth (137). HpLV epidemiology is consistent with very short range spread with minimal influence of inoculum from outside the yard of interest. In contrast, HpMV spread patterns are more consistent with local (within the yard) spread coupled with background (outside the yard) infection, suggesting HpMV was introduced to the yards by aphid vectors, and subsequent localized spread occurred by mechanical means or aphid vectors moving along rows $(133,134)$. In comparative studies in the United States, the spatial distribution of cv. Horizon plants infected by $\mathrm{HpLV}$ and AHLV was strongly influenced by plant contact. In contrast, HpMV infection in cv. Horizon and Nugget plants was autocorrelated along rows and unaffected by basal growth contact (135), suggesting that mechanical transmission rather than direct plant contact is important for HpMV within yards. Analyses of the associations between $\mathrm{HpLV}$ and HpMV in Australian yards have also consistently suggested a strong positive association across cultivars and locations (136), probably reflecting shared means for localized spread once established in yards (47).
Effect of carlaviruses on yield and levels of brewing organic acids. There are limited data on the influence of individual carlaviruses on hop growth, yield, and product quality due to the difficulty of establishing and maintaining comparative field trials over multiple seasons, and the high natural incidence of co-infections with multiple viruses and viroids. A summary of currently available data is given in Table 1.

As previously mentioned, HpMV infection in mosaic-sensitive cultivars results in a severe and often lethal reaction (182). In many other cultivars, the influence of carlavirus infections is less deleterious and variable. Chambers et al. (38) reported that over 4 years there was minimal difference in cone yield and alpha acid content between plants of cv. Northdown infected by HpLV, compared with those infected with both HpLV and HpMV. Cultivar Challenger, however, was found to yield slightly more in the absence of HpMV. In the United States, significant deleterious effects on agronomic characteristics and yield have been attributed to HpLV and HpMV in cv. Chinook. Both viruses significantly reduced lateral length, leaf weight, and the number of nodes per lateral. The height of plants infected by HpMV was also significantly reduced. All yield parameters (cone yield, dry matter content, the number of cones per plant, and levels of brewing organic acids and oils) were also significantly reduced by these viruses (147)

In Australia, infection by HpMV in cv. Pride of Ringwood reduced yield by 50 to $54 \%$ and alpha acid levels by 11 to $19 \%$ in each of 2 years (138). Infection by HpLV in cv. Agate was also associated with significant reductions in plant height, losses in dry cone yield varying from 40 to $70 \%$, a $44 \%$ reduction in alpha acid levels and the cohumulone portion of the alpha acids, and a $42 \%$ reduction in the alpha to beta acid ratio in the first year of production. However, in the second year, no significant reductions in brewing organic acids were detected. In the same study, infection by $\mathrm{HpLV}$ and HpMV did not deleteriously affect the agronomic characteristics or yield in cv. Super Pride (139). Significant reductions in yield from individual carlaviruses and their combinations have also been reported in commercial yards in New Zealand (75).

HpMV infection has also been suggested to increase susceptibility of hops to the root rot pathogen Phytophthora citricola (141).

\section{ApMV}

Infection of hop by an ilarvirus was first suggested following transmission of a virus from hop to cucumber (Cucumis sativus), giving rise to symptoms indistinguishable from those induced by isolates of Prunus necrotic ringspot virus 
(PNRSV) (64). Bock (27) showed this virus was at high prevalence and incidence in commercial yards. Bock (28) described two isolates of PNRSV in hop, designated PNRSV-A (apple) or PNRSV-C (cherry) serotype depending upon the strength of their reactions in Ouchterlony double diffusion tests with antisera prepared against an ApMV isolate from Malus spp. and a PNRSV isolate from Prunus spp. Fulton (65) further demonstrated that Bock's 'A' isolate was serologically identical to ApMV, while the ' $C$ ' isolate was closely related to PNRSV from Prunus spp. Barbara et al. (23) also described isolates from hop similar to Bock's 'A' type that reacted strongly with antiserum produced against an apple isolate (ApMV-P) but did not react with antisera against a cherry isolate (PNRSV-G). This study also identified isolates that reacted moderately with both antisera and were similar to Bock's hop ' $C$ ' type. However, because these isolates did not react as strongly with ApMV-P antisera as ' $A$ ' types, or as strongly to PNRSV-G as isolates from cherry, they redefined Bock's 'C' serotype to 'I' (intermediate). This distinguished this serotype from true ' $A$ ' and ' $C$ ' types that occur singly or as mixtures only in Prunus spp. (cherry and plum) and other Rosaceous species. Only 'A' serotypes have been found in Malus spp., while both 'A' and ' $\mathrm{I}$ ' serotypes occur in hop. Studies from the United States also characterized two isolate types from hop, designated 'HP-1' and 'HP-2'. These were distinguished by differential symptom production in herbaceous indicator species, Chenopodium hybridum and C. berlandieri. Further serological testing identified 'HP-2' as an intermediate isolate and 'HP-1' as similar to ApMV (174). Nucleoprotein analysis of ilarvirus isolates also found that isolates from hop were distinct to those from Prunus spp. or rose (45). Analysis of RNA sequences of the capsid gene have further substantiated that both ilarvirus serotypes from hops are strains of ApMV, but distinct from those infecting Malus spp., and demonstrated that 'Shirofugen' flowering cherry assays may be used to differentiate strains based on hypersensitivity (46). Eppler (59) has identified the cherry serotype of PNRSV in wild hop in Germany, but to our knowledge there are no confirmed reports of PNRSV in cultivated hop. The ilarvirus serotypes infecting hop are therefore now referred to as ApMVintermediate (ApMV-I) and ApMV-hop (ApMV-H) to reflect the distant serological relationship with PNRSV and the closer but phylogenetically distinct relationship with ApMV from Malus spp. (46). No evidence has been found of co-infections between these serotypes in hop $(37,46)$.

ApMV virions consist of three quasispherical or slightly pleomorphic particles, ranging in diameter between 25 and 29 nm. Each particle contains one component of the tripartite single-stranded RNA genome of approximately $2.1,3.0$, and 3.5 $\mathrm{kb}$. These particles and the coat protein are all required for infection (23).

Symptoms of ApMV in hop range from chlorotic ringspots that can become necrotic (Fig. 3), oak-leaf line patterns (Fig. 4), to latency. If symptoms are expressed, they are usually found after rapid changes in temperature (23).

Spatial patterns of ApMV epidemics. ApMV spread in hop yards is generally slow but strongly influenced by cultivar. For example, studies in the United Kingdom have found that ApMV infected 30\% of cv. Northern Brewer plants over a 4year period, but increased more slowly in cv. Wye Northdown (9\% of plants over 6 years). In a separate cv. Wye Northdown yard, $26 \%$ of plants became infected with ApMV over a 10 -year period (183). Studies in New Zealand in a cv. Superalpha yard found no change in the incidence of ApMV over a 3-year period, but in a second yard of the same cultivar, the incidence of ApMV increased by $13 \%$ over the same period (76). In Australia, infection by ApMV is also highly variable and dependent on cultivar. In cv. Pride of Ringwood, ApMV was not detected in several 19-yearold yards. However, in cv. Victoria yards, almost $100 \%$ of the plants were infected only 7 years after planting with virustested material (140). Similar rapid spread of ApMV into newly established yards has also been reported in cv. Agate (139).

Quantitative analyses of the spatial pattern of ApMV epidemics in Australia have consistently suggested significant autocorrelation of infected plants in the same direction as mechanical agronomic operations, such as slashing to control basal growth (137). Spatiotemporal analyses provided further evidence of localized spread of ApMV but could not exclude the influence of inoculum sources from outside the yard (133).

Table 1. Influence of hop viruses on cone yields and brewing alpha acid levels (adapted from Wilson et al. [199])

\begin{tabular}{|c|c|c|c|c|c|c|c|c|c|c|c|}
\hline \multirow[b]{3}{*}{ Cultivar } & \multicolumn{10}{|c|}{ Yield loss (\%) } & \multirow[b]{3}{*}{ Ref. } \\
\hline & \multicolumn{2}{|c|}{ ApMVa } & \multicolumn{2}{|c|}{ HрMVа } & \multicolumn{2}{|c|}{ HpLVa } & \multicolumn{2}{|c|}{ ArMV-Ha } & \multicolumn{2}{|c|}{ Multiple infections } & \\
\hline & Cone & $\begin{array}{l}\text { Alpha } \\
\text { acids }\end{array}$ & Cone & $\begin{array}{l}\text { Alpha } \\
\text { acids }\end{array}$ & Cone & $\begin{array}{l}\text { Alpha } \\
\text { acids }\end{array}$ & Cone & $\begin{array}{l}\text { Alpha } \\
\text { acids }\end{array}$ & Cone & $\begin{array}{l}\text { Alpha } \\
\text { acids }\end{array}$ & \\
\hline \multicolumn{12}{|l|}{ United Kingdom } \\
\hline Fuggle & 8 & 0.5 & -b & - & - & - & 39 to 96 & 4 to 15 & - & - & 17 \\
\hline Cascade & 20 & 3 & - & - & - & - & - & - & - & - & 17 \\
\hline Bullion & 20 & 2 & - & - & - & - & - & - & - & - & 17 \\
\hline Wye Northdown & 32 & 8 & - & - & - & - & - & - & - & - & 119 \\
\hline \multicolumn{12}{|l|}{ Germany } \\
\hline Hüller Bitter & - & - & - & - & - & - & - & - & 34 & 20 & 87 \\
\hline Northern Brewer & - & - & $0^{\mathrm{c}}$ & 0 & 0 & 0 & - & - & - & 26 & 87 \\
\hline Hersbrucker Spät & - & - & 0 & 0 & 0 & 0 & - & - & 5 to 38 & 0 to 47 & 87 \\
\hline \multicolumn{12}{|l|}{ USA } \\
\hline Chinook & - & - & 62 & 0 & 0 & 12 & - & - & - & - & 147 \\
\hline \multicolumn{12}{|l|}{ New Zealand } \\
\hline Superalpha & - & - & - & - & 0 & 0 & 0 & 0 & 0 to 39 & 0 to 4 & 75 \\
\hline \multicolumn{12}{|c|}{ Australia } \\
\hline Pride of Ringwood & 0 to 50 & 0 to 10 & 50 to 53 & 0 to 18 & 0 to 20 & 0 & 45 & - & 0 to 39 & 0 to 12 & 138 \\
\hline Victoria & 0 & 0 & 0 & 0 & 0 & 0 & 0 & 0 & 0 to 43 & 0 & 138 \\
\hline Nugget & 0 & 0 to 10 & 0 & 0 & 0 & 0 & 0 & 0 & 0 & 0 & 138 \\
\hline Opal & 0 & 0 & 0 to 27 & 0 & 40 to 42 & 0 & - & - & 0 to 58 & 23 to 43 & 138 \\
\hline Super Pride & - & - & 0 & 0 & 0 & 0 & - & - & - & - & 139 \\
\hline Agate & - & - & 0 & 0 & 0 to 70 & 0 to 44 & - & - & - & - & 139 \\
\hline
\end{tabular}

a ApMV = Apple mosaic virus; $\mathrm{HpMV}=$ Hop mosaic virus; $\mathrm{HpLV}=$ Hop latent virus; $\mathrm{ArMV}-\mathrm{H}=$ Arabis mosaic virus hop strain.

b $-=$ Not tested.

c $0=$ No significant effect. 
Transmission of ApMV. The transmission of ApMV between plants in commercial yards is predominantly by mechanical means (132). This is notable as many other ilarviruses are commonly transmitted in association with thrips and infected pollen $(66,67,109)$. In the ApMV-hop pathosystem, the role of pollen is not considered important for several reasons, including: (i) in the United Kingdom the shift from seeded to seedless hop production by removing male plants was not associated with significant decreases in the rate of ilarvirus infection; (ii) male plants can become infected by ApMV; and (iii) transmission occurs to both flowering and deflowered plants $(120,153)$. The autocorrelated and predominantly local spread patterns suggested by spatial pattern analyses

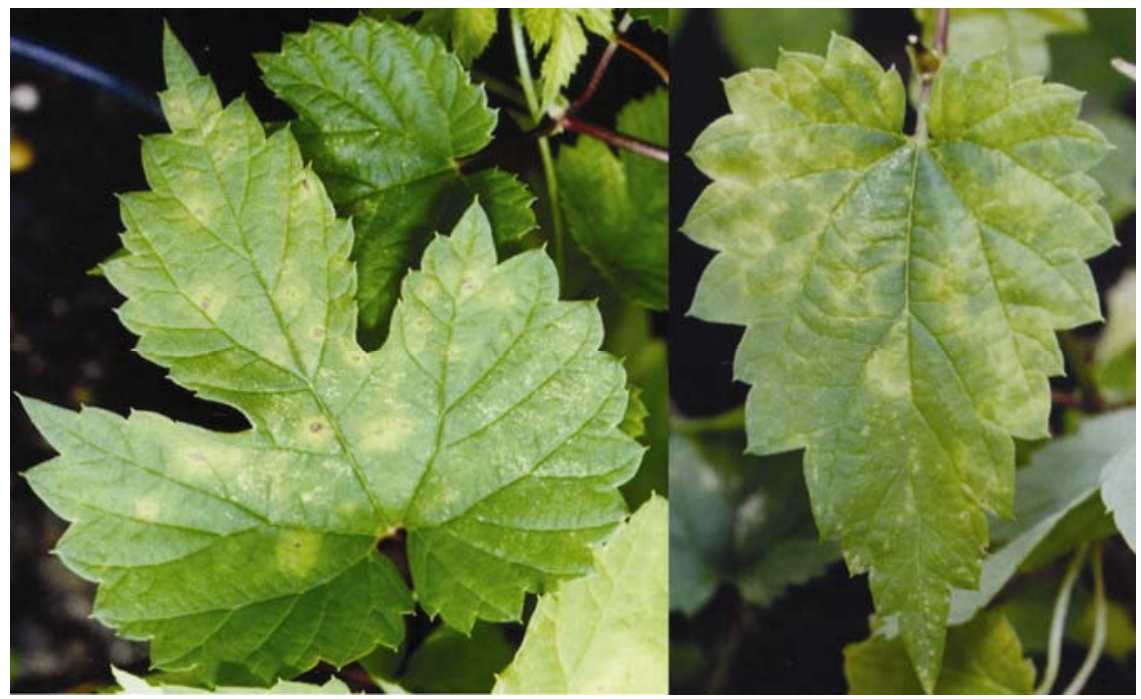

Fig. 3. Chlorotic rings (right) and necrotic spots (left) on leaves infected by Apple mosaic virus in hop cultivar Opal.

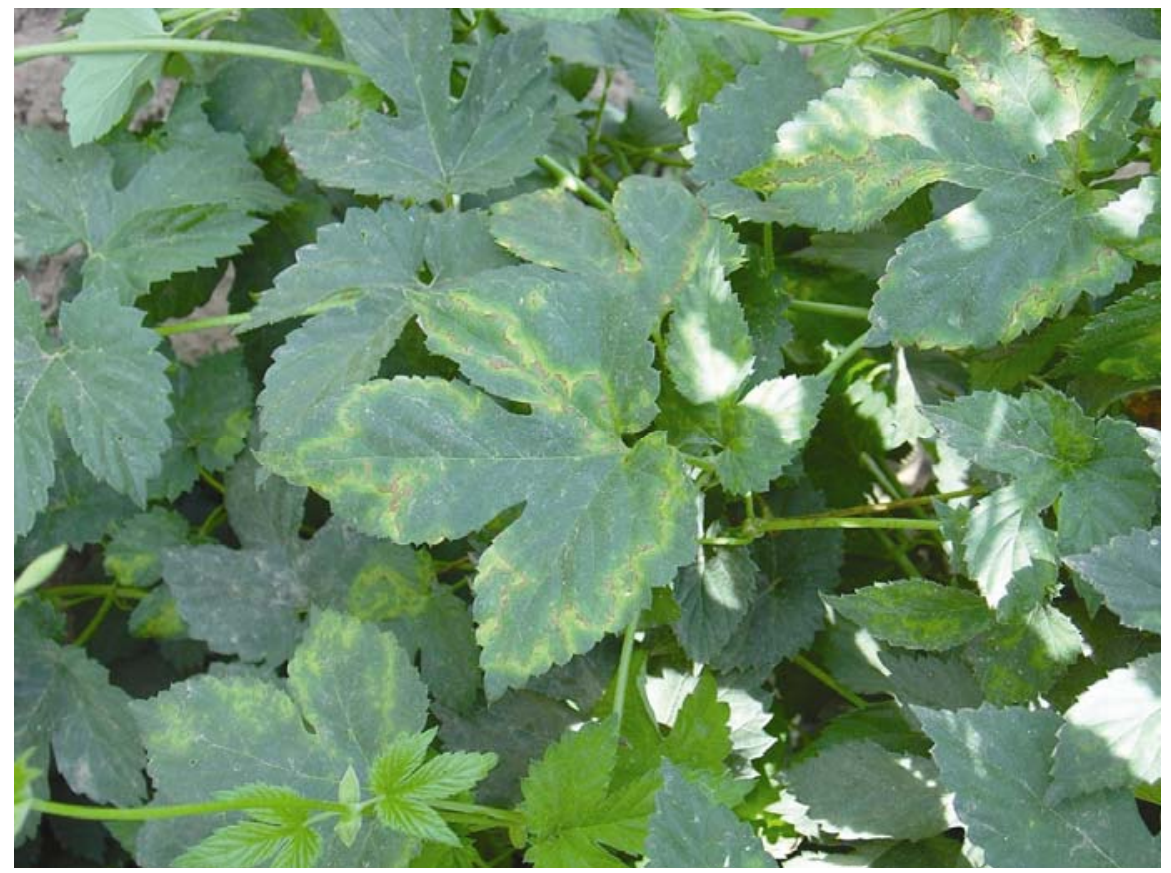

Fig. 4. Infection by Apple mosaic virus can also cause oak-leaf patterns. Symptoms pictured here are in hop cultivar Willamette. dom $(185)$ and Australia $(133,137)$ are also not suggestive of transmission by pollen. Although unknown soilborne vectors have been suggested $(183,185)$, mechanical transmission has been demonstrated in glasshouse studies through direct plant contact, transfer of infective sap to leaf and root tissues, simulated pruning, and root grafting, but not simple root contact (60,132). Under field conditions, ApMV transmission can be reduced by preventing contact between neighboring plants early in the season through the use of desiccant herbicides such as paraquat, or similar strategies $(132,199)$.

Effect of ApMV on yield and levels of brewing organic acids. ApMV is regarded as one of the most deleterious viruses to of ApMV epidemics in the United King- hop production, but the effect is dependent upon cultivar (summarized in Table 1). It has been reported that ApMV-free cv. Fuggle plants had higher alpha $(0.5 \%)$ and beta $(0.3 \%)$ acids and yields $(8 \%)$ than infected plants (17). Cultivar Cascade plants free of ApMV had 2.8\% higher alpha acids, $1.4 \%$ higher beta acids, and $20 \%$ higher yields. Plants of cv. Bullion had $1.5 \%$ higher alpha acids and $20 \%$ higher yields when ApMV-free, but beta acids were not affected. Neve and Lewis (118) showed that cones from ApMV-free plants grown in the United Kingdom had 0.7 to $2 \%$ higher alpha acid content than infected plants, but with no increase in cone yield. Among three cultivars, Neve and Lewis (119) found ApMV caused an average decrease in yield of $16 \%$ and an $11 \%$ reduction in alpha acids. Similarly, ApMV reduced cone yield by $32 \%$ and alpha acid levels by $8 \%$ in cv. Wye Northdown. Neve and Thresh (120) summarized much of this research and showed that five cultivars freed of ApMV had increments in yield of 3 to $21 \%$ and alpha levels of 4 to $16 \%$.

In Germany, comparisons between plots of ApMV-infected and virus-tested cv. Hüller Bitter over a 3-year period consistently recorded reductions in alpha acid content of 21,18 , and $22 \%$, respectively, in each year. In a later study, the alpha acid content of ApMV-infected cvs. Hüller Bitter and Northern Brewer was 18 to $26 \%$ lower than in virus-tested plants (87).

In Australia, ApMV has been associated with an increase in softwood cutting mortality following propagation and a decrease in cone yield and levels of brewing organic acids. In cv. Nugget, plants infected by ApMV-I had 11\% lower alpha acids and $7 \%$ lower beta acid levels. In cv. Opal, significant reductions in yield and alpha acid levels were reported with both ApMV serotypes when present in co-infection with the carlaviruses HpMV and HpLV. In cv. Victoria, infection by the individual viruses had no effect in the first year of the study, but significant reductions from some virus combinations were reported, suggesting an exacerbation of the deleterious effects of viruses as plants become older (138). Yield reductions from ApMV-H have also been reported in cv. Superalpha in New Zealand. In this study, these effects were attributed to reductions in individual cone weight and the numbers and weights of bracteoles, and lower alpha acid levels resulted from a smaller number of bracteoles with fewer lupulin glands (75).

\section{ArMV Hop Strain (ArMV-H)}

The most common nepovirus found in hop is the hop strain of ArMV (ArMV-H). ArMV-H has been reported in commercial hop yards in several countries, including Belgium (93), the former Czechoslovakia (145), France (54), Germany (104), New Zealand (76), South Africa (196), and the 
United Kingdom (188). In Australia $(36,197)$ and the United States (77), there are historical, but no recent reports $(112,171)$ of ArMV-H or diseases attributable to this virus, suggesting it was subsequently eradicated. In Australia, eradication was attributed to a widespread shift from imported English varieties to the locally bred cv. Pride of Ringwood and the absence of the nematode vector (112). In other countries, such as New Zealand, ArMV-H was apparently transmitted from imported English cultivars to locally bred ones and became endemic (76) due to the introduction and establishment of the nematode vector Xiphinema diversicaudatum into hop yards (74).

Infection by ArMV-H has been associated with several diseases, including barebine or spidery hop, split leaf blotch, nettlehead, and hop chlorotic disease (189). Symptoms of barebine or spidery hop are apparent in early spring as weak shoot growth, curvature of shoots, and production of small, dark-colored leaves. Symptoms of split leaf blotch include translucent, yellow oily blotches between the leaf veins, leading to leaves splitting upon expansion (Fig. 5A; 190). Cultivar Fuggle is particularly susceptible, exhibiting symptoms referred to as severe blotch. Less severe symptoms (slight blotch) have been reported in other cultivars, but the association of these symptoms with ArMV-H is yet to be ascertained.

Nettlehead was described in detail by Salmon and Ware (157) and is one of the most damaging viral diseases of hop (42,90). Symptoms become progressively more severe until plant death 5 to 6 years after infection (78). Plants with nettlehead often exhibit symptoms of barebine early in the season. Later, plants develop stiff, erect shoots with short internodes that fail to climb and fall away from support strings (Fig. 5B and D). Other symptoms of nettlehead included upward rolling of the leaf margins, vein clearing or mottle, and enations on the abaxial leaf surface (50). Cultivars WGV, Fuggle, and Yeoman are particularly susceptible, while others such as Bramling Cross are tolerant. Understanding the etiology of nettlehead was complicated by the ephemeral nature of symptoms. However, the role of a satellite nucleic acid (SNA) in nettlehead was demonstrated by Davies and Clark (50). Symptom severity was related to the amount and particular species of SNA present $(50,51)$. In Germany (105) and New Zealand (76), infection by ArMV-H was latent. This suggests differences in cultivar susceptibility, variation in the pathogenicity of isolates, or absence of the relevant SNA.

Hop chlorotic disease was first described by Salmon and Ware (158). The disease occurs sporadically and is transmissible via seed, graft, and sap inoculation. Symptoms include severe distortion of developing foliage on the lower parts of bines (Fig. 5C), with leaves often assuming a characteristic parrot beak shape. The disease is associated with a specific ArMV$\mathrm{H}$ strain that can be differentiated from other strains by the presence of systemic symptoms in Chenopodium amaranticolor and $C$. quinoa but not by serology $(6,9)$. The disease has also been reported in Germany, Russia, and Poland (9).

Particles of ArMV are isometric in shape, approximately 25 to $27 \mathrm{~nm}$ in diameter (114), with a single capsid protein with a molecular mass of approximately 54 $\mathrm{kDa}$. The genome of nepoviruses is bipartite with both RNA-1 and RNA-2 necessary for infection and multiplication. The ArMV-H associated SNA is 300 nucleotides in length and makes up some $80 \%$ of the nucleic acids of purified preparations $(50,80)$. Multiplication of ArMV-H associated SNA is not supported by strains of ArMV from other hosts (51). Wetzel et al. (198) demonstrated a $96 \%$ homology between the amino acid sequences of the protein 2A of ArMV-H and ArMV from sugar beet, and suggested the same strain may infect both species.

Transmission of ArMV-H. ArMV-H is transmitted by the dagger nematode, Xiphinema diversicaudatum (193). Other nema- tode species have been implicated in the spread of ArMV; however, the evidence is weak (192). X. diversicaudatum is indigenous to the United Kingdom and is widespread in arable permanent pasture, deciduous woodlands, and hop production areas (30). The nematode occurs throughout Europe but is of limited distribution in North America, Australia, and New Zealand (18). $X$. diversicaudatum is a relatively long-lived nematode with a life cycle of up to 3 years, while individual females may live for more than 5 years (143). It can live, but not multiply, in soil without higher plants for 3 years (102). While information on ontogenetic development on hop is lacking, a laboratory study of $X$. diversicaudatum on strawberry ( $F r a-$ garia $\times$ ananassa) demonstrated adult females survive approximately 60 weeks, with a reproductive period of 36 weeks and reproductive capacity of 180 to 200 progeny (31). Development from egg to adult took 12 weeks or 1,092 degree-days assuming a basal temperature of $5{ }^{\circ} \mathrm{C}$. Each of the four juvenile stages and adults are found at all times, but there can be an increase in the proportion of mature females during seasonal flushes of new growth, at which time egg-laying occurs with hatch

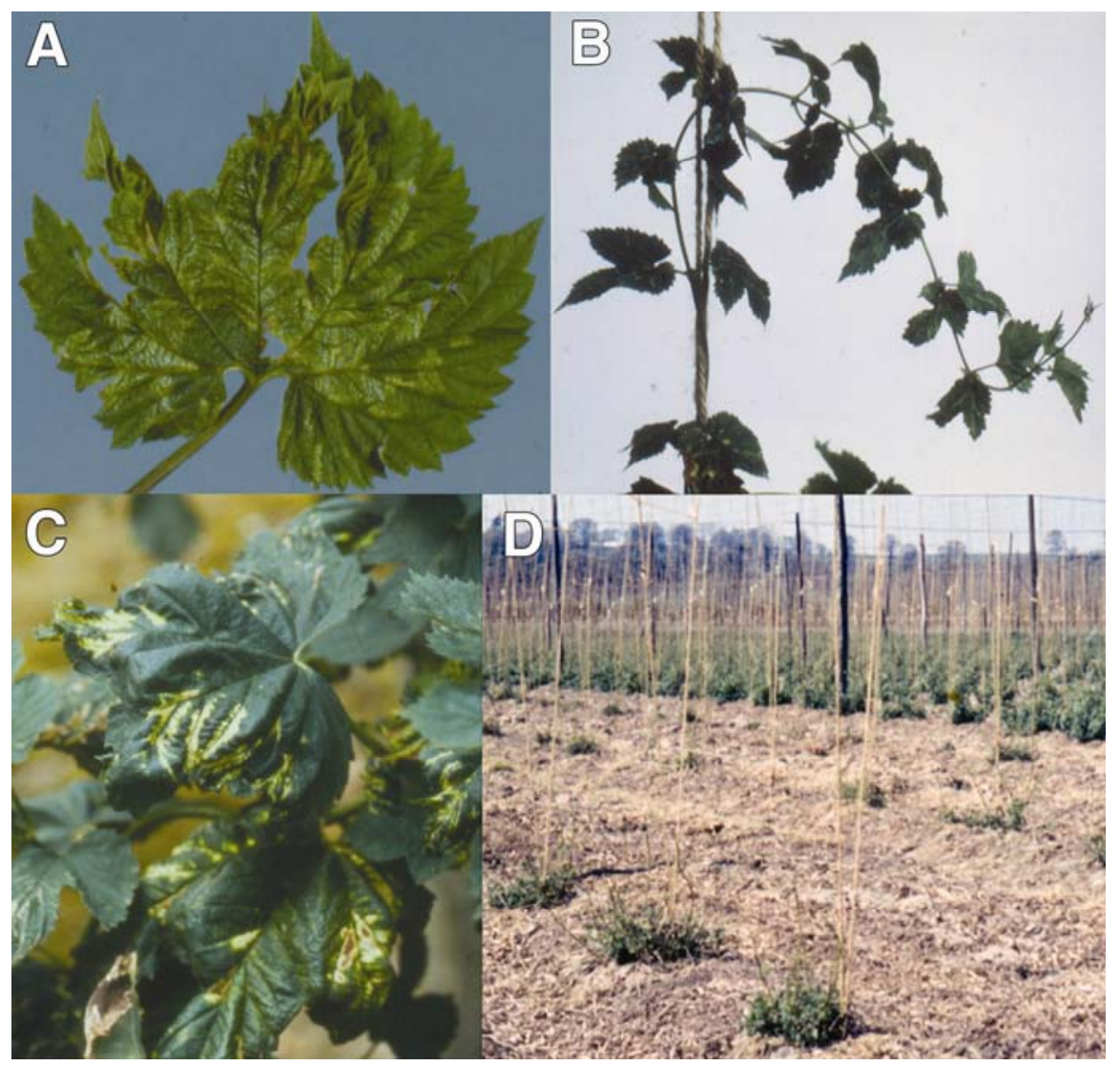

Fig. 5. A, Leaf symptoms of split leaf blotch caused by Arabis mosaic virus hop strain (ArMV-H). B, Symptoms of nettlehead include a failure to climb support strings leading to a falling away of the bines. C, Foliar symptoms of hop chlorotic disease caused by ArMV-H. D, Barebine/nettlehead in a typical spreading patch in cv. Fuggles. The plants in the foreground have weak shoots and few leaves typical of nettlehead affected plants in early spring. Unaffected plants in the background are more vigorous and leafy. (Images A, B, and D, courtesy J. Mike Thresh) 
occurring shortly thereafter (178). The rate of reproduction is low, with a mean of 7.3 juveniles per year on strawberry (62), which is a relatively better host of $X$. diversicaudatum than hop (43). However, the hop root system occupies several cubic meters, so even a density of 1 nematode per $200 \mathrm{ml}$ of soil equates to thousands per plant, providing substantial opportunity for virus transmission (189).

Adults and juveniles of $X$. diversicaudatum transmit ArMV with equal efficiency (68) and remain infective for up to 44 and 36 weeks, respectively, in the absence of host plants (193). Infectivity can be retained by nematodes for periods of up to 8 months when they are given access to hosts that are virus immune (69). McNamara and Pitcher (107) found X. diversicaudatum was more efficient at transmitting ArMV-H from hop than ArMV from strawberry. The virus is not retained through the molt between stages of the life cycle and is not passed from the female to egg. Detailed studies on the acquisition time necessary for nematodes to become viruliferous with ArMV-H are lacking in hop. However, $X$. index acquired the ability to transmit Grapevine leaf roll virus after only 5 minutes (16). chanically. Davies and Clark (50) reported the efficiency of mechanical transmission of ArMV-H from hop to C. quinoa or hop was less than $10 \%$. Conversely, Eppler (53) was unable to transmit ArMV-H mechanically between hop plants. Therefore, sap transmission is now considered of minor importance under field conditions. Eppler (53) provided some evidence for pollen transmission of ArMV-H, but further work is required to substantiate this finding. ArMV-H can also be transmitted by dodder and is seedborne in hop (114), with up to $50 \%$ of the seedlings from diseased plants infected (189). In seeded crops, where seeds were scattered widely after harvest, infected seedlings were common in spring, allowing nonviruliferous nematodes to acquire ArMV-H $(186,189)$.
ArMV-H can also be transmitted me-

Spatial patterns of ArMV-H epidemics. Early reports of the spread of ArMV-H infected plants describe a range of spatial patterns $(78,189)$. Later, these were attributed to the virus status of the planting material and the spatial distribution of $X$. diversicaudatum (Table 2). In New Zealand, where hop yards are generally uncultivated, $X$. diversicaudatum was detected in six out of eight commercial hop yards examined, with over $90 \%$ of samples from which it was detected occurring at yard edges (74). Spread of ArMV-H in a hop yard can be relatively rapid. In the United Kingdom, the incidence of ArMV-H increased from 2.9 to $43.6 \%$ after the first 6 years (8) and to $61.8 \%$ by year 12 (184) in a hop yard planted with potentially infected material and where $X$. diversicaudatum was widely distributed. This rapid spread is at odds with the small distances with which $X$. diversicaudatum migrate through soil (only 0.3 to $2.0 \mathrm{~m}$ annually) $(69,103,179)$. However, more rapid progress of ArMV-H through a yard would be facilitated by systemic movement within the large root systems and the close planting distances, especially within rows, that would allow roots of infected and healthy plants to intertwine, and provide potential for nematode transmission. Adams et al. (8) demonstrated that close spacings facilitated transmission of ArMV-H, with a greater probability of spread from hop plants with symptoms of ArMV-H to the next plant $1 \mathrm{~m}$ away within the row (35\%) than to those $2 \mathrm{~m}$ away within or across the rows $(9 \%)$. Thresh (181) related the probability of infection to the number of neighboring plants with symptoms and obtained a curvilinear relationship of 26 to $100 \%$ for plants with one to eight infected neighbors.

Effect of ArMV-H on yield and levels of brewing organic acids. The effects of ArMV-H on cone yield and levels of brewing organic acids are summarized in Table 1. In the United Kingdom, barebine was associated with yield reductions of 23 to $26 \%$ in comparison with healthy plants in

Table 2. Influence of the presence or absence of Xiphinema diversicaudatum and virus status of planting material on the subsequent pattern of spread of Arabis mosaic virus hop strain (ArMV-H) in hop yards (adapted from 189)

\begin{tabular}{|c|c|c|}
\hline \multirow[b]{2}{*}{$X$. diversicaudatum } & \multicolumn{2}{|c|}{ Virus status of planting material } \\
\hline & Virus-tested & Infected \\
\hline Absent & No infection and spread & $\begin{array}{l}\text { Random distribution of diseased plants } \\
\text { but no secondary spread }\end{array}$ \\
\hline $\begin{array}{l}\text { Present and } \\
\text { nonviruliferous }\end{array}$ & No infection and spread & $\begin{array}{l}\text { Random distribution of diseased plants } \\
\text { followed by slowly expanding foci in } \\
\text { areas containing both infected plants } \\
\text { and viruliferous vector }\end{array}$ \\
\hline $\begin{array}{l}\text { Present and } \\
\text { viruliferous }\end{array}$ & $\begin{array}{l}\text { Patches of diseased plants } \\
\text { with slowly expanding } \\
\text { foci in areas where vector } \\
\text { is present }\end{array}$ & $\begin{array}{l}\text { Random distribution of diseased plants } \\
\text { with no secondary spread in areas } \\
\text { devoid of vector, patches of infected } \\
\text { plants with slowly expanding foci in } \\
\text { areas where vector is present }\end{array}$ \\
\hline
\end{tabular}

cv. Bullion (191), and cones from diseased plants had alpha acid contents of $6.5 \%$ (by weight) in comparison with $7.1 \%$ in healthy plants. Plants with barebine or spidery hop recovered following the removal of weak shoots during training, but often developed split leaf blotch or nettlehead later in the season. Severe blotch has been demonstrated to reduce cone yield by up to $50 \%$ (189). The yield of nettleheadaffected plants can be reduced by over $75 \%$ in susceptible cultivars and in some cases caused yards to be removed (116,122). In Australia, Johnstone (78) reported yield losses of 25 to $45 \%$ from nettlehead, with no reduction in alpha acids. In New Zealand, significant yield losses were demonstrated despite the absence of symptoms. In two trials, plants of cv. Superalpha infected with ArMV-H and HpLV or ArMV-H, HpMV, and HpLV had cone yields of 71 and $73 \%$ less compared with plants infected with HpLV or HpMV and $\mathrm{HpLV}$, respectively, with no effect on alpha- or beta-acid levels (76).

\section{HpSVd}

Hop stunt disease was first identified in hop yards in Japan, initially thought to be associated with infection by a virus and referred to as cedar-shaped hop or dwarf hop (201), but later found to be induced by infection with a viroid (163). The disease has been reported in commercial yards in Japan (160), Korea (89), and the United States in 2004 (K. C. Eastwell, unpublished data).

The viroid consists of covalently closed single-stranded RNA of 294 to 303 nucleotides depending on host and isolate (123). $\mathrm{HpSVd}$ has a moderately wide host range and has been found naturally infecting many woody perennial species including plum (Prunus spp.), almond (Prunus dulcis), citrus (Citrus sp.), grapevine (Vitis spp.), and pomegranate (Punica granatum) (19). Five distinct groups of HpSVd sequence variants have been isolated from different hosts (88). HpSVd isolates from hop have the highest sequence similarity to those from grapevine (162). Experimental infection of hop with HpSVd from several woody hosts has been demonstrated, suggesting possible risk to hop production from natural alternate host reservoirs $(86,159)$.

HpSVd infected plants typically have shortened internodes on the main and lateral bines, reducing plant height to approximately $3 \mathrm{~m}$. Upper leaves appear curled, smaller in size, and chlorotic. Foliar symptoms of HpSVd may vary. In Japan, infected leaves droop from the base creating a characteristic $\mathrm{X}$ formation with laterals. Other foliar symptoms associated with $\mathrm{HpSVd}$ infection are a yellow-green color on the basal foliage early in the season, while yellow speckling along the major veins may also be present (Fig. 6). However, diagnosis based on symptoms 
may be difficult because of their ephemeral nature, and dependence upon cultivar and climate. In general, stunting is more severe in warmer climates $(159,160)$.

Transmission and spatial patterns of spread of HpSVd. Transmission of HpSVd within hop yards is solely through mechanical means and probably facilitated by harvesting or cultural operations such as stringing and mechanical basal growth control. The only method for long-distance spread of HpSVd is through infected propagation material. Within yards, HpSVd spreads along rows, reflecting the role of cultural operations in transmission $(162,201)$.

Effect of HpSVd on yield and levels of brewing organic acids. Plants infected by HpSVd produced fewer and smaller cones with yields $50 \%$ lower, and alpha and beta acid levels 50 to $70 \%$ lower than in viroidfree plants $(164,201)$. The proportions of the brewing organic acids are also altered by HpSVd. Ratios of beta to alpha acids less than 1:20 are characteristic of healthy plants, whereas ratios greater than 1:44 are typical of HpSVd infection (164). Momma and Takahashi (110) reported that the number of lupulin glands was reduced by more than $60 \%$ in cones.

\section{HpLVd}

The presence of a second viroid infecting hop was first suggested by Pallas et al. (128) and initially termed "hop viroid-like RNA fast, or HV-f". It was subsequently described and named HpLVd in reference to the latent nature in the majority of hop cultivars $(151,152)$. The viroid is a covalently closed single stranded RNA of 256 nucleotides distinct from $\mathrm{HpSVd}$ (with only $45 \%$ sequence homology) (151). Although viroids, including $\mathrm{HpSVd}$, generally form complex populations of natural sequence variants called quasispecies, no such variants have been reported for HpLVd.

HpLVd has been reported from commercial yards in the United Kingdom $(10,14,24)$, Germany (84), New Zealand (73), Korea (89), Poland (175), Slovenia (85), Japan (71), Czech Republic (101), Brazil, in material recently imported from the United States (63), United States (115), and Australia (D. Crowle, personal communication). In the majority of these areas, the incidence of HpLVd is considered high or ubiquitous. For example, Puchta et al. (152) surveyed 14 yards of cv. Northern Brewer in Germany and found only 1 of 27 samples free of HpLVd. The worldwide distribution of $\mathrm{HpLVd}$ is probably due to its efficient mechanical transmission and dissemination in vegetative propagules, the latter being made more likely by HpLVd's latent nature. In addition to the commercial hop, HpLVd also infects $H$. japonicus and stinging nettle (Urtica dioica) (84).

Symptoms caused by infection with HpLVd have been described in cv. Omega in the United Kingdom (25). These included chlorosis, slow growth, and the production of fewer laterals with smaller cones $(10,25)$.

Transmission and spatial patterns of HpLVd spread. The spread of HpLVd in a commercial yard is predominantly localized and to adjacent plants, reflecting the mechanical means of transmission, including harvesting and cultural operations $(11,14)$. The main means by which HpLVd is introduced into commercial yards is in infected propagation material. No evidence for long-distance spread, such as by encapsidation in co-infecting viruses and subsequent spread by aphids, has been found (11). Low transmission efficiency has been reported through pollen transfer or by seed $(49,98)$. Once HpLVd is introduced into commercial yards, the spread can be rapid but is influenced by cultivar susceptibility. High re-infection rates of $65 \%$ within 3 years have been described in the Czech Osvald's clone 72 (98). In cv. Omega yards in the United Kingdom, $75 \%$ of viroid-free plants became infected within 2 years, while in cv. Wye Northdown, minimal spread was observed (14). Cultivar and region have also been found to significantly affect $\mathrm{HpLVd}$ concentration. In the United Kingdom, HpLVd concentration is higher later in the season (being high enough for reliable detection from late spring onward) and generally higher at the base of the plant (111). The titer of HpLVd is also high in roots (101). In the warmer climate of Germany, HpLVd titer was found to slightly decrease in summer (84).

Effect of HpLVd on yield and levels of brewing organic acids. The effects of HpLVd on cone yield and levels of brewing organic acids are strongly dependent upon genotype. For example, in cv. Omega, cone yield was reduced by $27 \%$ and alpha-acids levels by $31 \%$. Moreover, beta-acids levels and oil content were higher in HpLVd-infected plants, suggesting infection may hasten cone maturation (25). Changes to the expression of host components involved in the synthesis of secondary host metabolites due to HpLVd infection were also suggested in trials conducted in the Czech Republic in Osvald's Clones 31, 72, and 114, and in cv. Premiant (130). In these trials, HpLVd infection decreased alpha acids by an average of $40 \%$, whereas beta acids levels, the ratios of humulone to cohumulone and lupulone to colupulone, were not affected. Levels of myrcene, $\alpha$ - and $\beta$-pinene were $29,37.4$, and $41.6 \%$ higher in infected plants. Levels of the sesquiterpenes, $\beta$ caryophyllene, $\alpha$-humulene, $\alpha$-copaene, $\gamma$ muurolene, $\beta$-bisabolene, $\gamma$-cadinene, and $\delta$-cadinene were also decreased by 13.7 , $13,14,18.5,29,21.7$, and $18.5 \%$, respectively, due to HpLVd infection. These changes in essential oil composition (in-

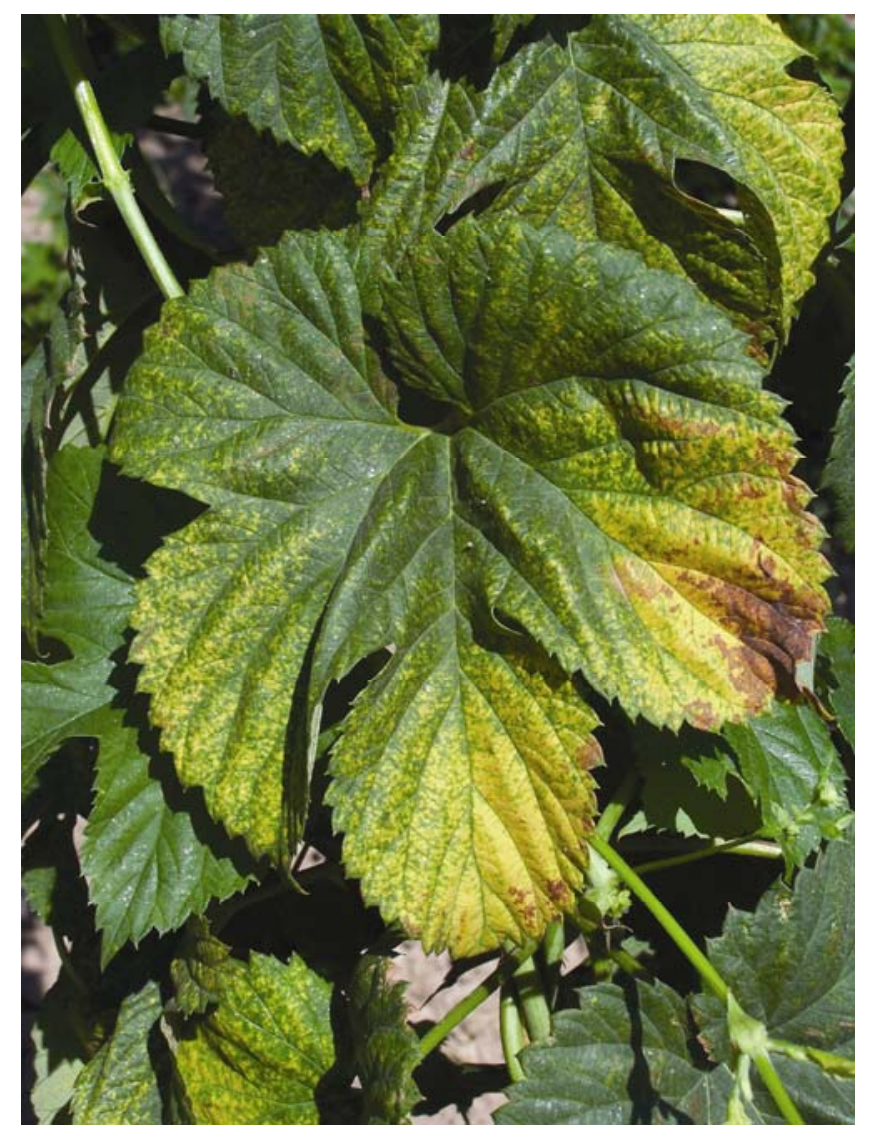

Fig. 6. Foliar symptoms of Hop stunt viroid in hop cultivar Willamette. (Courtesy D. H. Gent) 
crease in myrcene and general decrease of sesquiterpenes) are similar to those observed during cone maturation (108), but the associated decrease in alpha acids is not characteristic of this physiological change (130). The effects of HpLVd infection are less marked in cvs. Wye Northdown and Wye Challenger in the United Kingdom, but still resulted in reductions in total alpha-acid production of approximately 20\% (through smaller cones and reduced alpha-acids levels, both by ca. $10 \%$ ) and increases in myrcene levels (24). Infection by HpLVd also significantly reduced rooting of softwood cuttings and establishment (49).

\section{Minor Viruses and Virus-Like Agents Affecting Hop}

A range of viruses have been reported infecting hop at either a low prevalence or incidence and in localized regions. For the purposes of this review, we have therefore classified them as minor pathogens, recognizing that in particular pathosystems the status of these diseases relative to others may change. Limited information is available on their effect on cone yield and levels of brewing organic acids (Table 3 ).

\section{Management of Viruses and Viroids in Hop Production}

As with all pathosystems, effective management of disease caused by viruses and viroids in hop production requires a com- prehensive understanding of both their epidemiology and effects on yield and quality of cultivars in specific environments. This is most effectively demonstrated in the last 50 years of research examining the effect of viruses on different hop cultivars and in various parts of the world. This information clearly demonstrates that the effect of these viruses on yield and quality is strongly influenced by cultivar susceptibility and therefore requires assessment for each newly adopted cultivar. This principle is easily translated to other virus pathosystems. For example, if the effect on yield and/or quality of virus infection is significant but the rate of virus re-infection is slow, management may be achieved by planting with virus-tested material and roguing of any infected plants soon after they are identified. If, however, the effect on production is significant and the rate of re-infection is rapid, alternative methods of management need to be explored. Furthermore, if the cultivar is highly tolerant to infection, then the implementation of management strategies may not be cost effective (131). As strain variation within these viruses, such as ApMV and HpMV, has become more fully described, this adds further complexity in requiring quantitative yield loss information on the various virus strains, cultivars, and environment interactions.

Certification programs. Historically, vegetative propagation has been important in both disseminating and increasing the incidence of these pathogens. Hop viruses and viroids are passed efficiently from parent to progeny during vegetative propagation. The traditional means of hop propagation involved taking strap cuts. These are obtained by mounding soil over plants during seasonal cultivations in late summer. The buried basal portion of the bines becomes thickened and is cut off in winter for use as planting stock in spring. As strap cuts were taken after the plant had died back, there was usually no visual check on the health of the parent plant. Rapid degeneration of hop planting stocks in the United Kingdom has been attributed to this method of propagation (116). To address this problem, certification programs were established. Such programs seek to eliminate viruses and viroids from the propagation stock and avoid infection during the increase phase of vegetative propagation.

The effectiveness of certification programs has improved along with the sensitivity, reliability, and cost and time efficiency of detection methods. Although they often cause the greatest damage to individual plants, diseases with highly visible symptoms are generally easily detected and therefore more easily rogued, so that overall damage is minimized. Latent infections may cause less damage to individual plants, but they can become very important when inadequate detection allows them to occur at high incidence, leading to more overall damage.

Table 3. Minor viruses and virus-like agents reported affecting hop worldwide

\begin{tabular}{|c|c|c|c|}
\hline Virus/virus-like agent & Symptoms & Distribution & Literature \\
\hline Alfalfa mosaic virus (AlMV) Alfamovirus & $\begin{array}{l}\text { Systemic chlorotic spots in } \\
\text { cv. Styrian }\end{array}$ & China, former Czechoslovakia & 121,202 \\
\hline Cherry leafroll virus (CLRV) Nepovirus & No information & United Kingdom & 41 \\
\hline Cucumber mosaic virus (CMV) Cucumovirus & $\begin{array}{l}\text { Leaf distortion in cv. Hüller } \\
\text { Bitterer. Mottled foliage and } \\
\text { shortened internodes in } \\
\text { Humulus scandens }\end{array}$ & $\begin{array}{l}\text { Romania, Germany, } \\
\text { and United Kingdom }\end{array}$ & $27,96,97,165,166$ \\
\hline H-246 Hop virus (unclassified) & $\begin{array}{l}\text { Necrotic spots on stems, } \\
\text { shoots and leaves. Systemic } \\
\text { necrosis and death within } 2 \text { to } \\
3 \text { years following artificial } \\
\text { inoculation }\end{array}$ & Romania & 95 \\
\hline $\begin{array}{l}\text { Humulus japonicus latent virus (HJLV) } \\
\text { Ilarvirus syn. Humulus japonicus virus }\end{array}$ & Symptomless & $\begin{array}{l}\text { H. lupulus and H. japonicus in } \\
\text { China, imported H. japonicus } \\
\text { in United Kingdom }\end{array}$ & 12,169 \\
\hline $\begin{array}{l}\text { Petunia asteroid mosaic virus (PeAMV) } \\
\text { Tombusvirus syn. Tomato bushy stunt virus- } \\
\text { petunia strain }\end{array}$ & $\begin{array}{l}\text { Deformed asymmetric leaves } \\
\text { with necrotic crinkles, } \\
\text { ringspots, line-patterns, } \\
\text { chlorotic spotting, perforated } \\
\text { leaves, and general chlorosis }\end{array}$ & Former Czechoslovakia & $\begin{array}{l}121,145,173 ; \text { similar } \\
\text { symptoms reported by } \\
\text { Chod et al. (40) }\end{array}$ \\
\hline $\begin{array}{l}\text { Raspberry bushy dwarf virus (RBDV) } \\
\text { Idaeovirus }\end{array}$ & None reported & United Kingdom & 33 \\
\hline $\begin{array}{l}\text { Strawberry latent ringspot virus (SLRSV) } \\
\text { Nepovirus }\end{array}$ & None reported & Former Czechoslovakia & $\begin{array}{l}\text { 145; contrary to findings } \\
\text { of Valdez et al. (193) }\end{array}$ \\
\hline Tobacco mosaic virus (TMV) Tobamovirus & None reported & China & 200 \\
\hline Tobacco necrosis virus (TNV) Necrovirus & Necrotic local lesions & $\begin{array}{l}\text { Romania, France, } \\
\text { and former Czechoslovakia }\end{array}$ & $15,39,54,97$ \\
\hline Tobacco ringspot virus (TRSV) Nepovirus & Ringspots & Germany & 165 \\
\hline Apple fruit crinkle viroid (AFCVd) & $\begin{array}{l}\text { Stunting and severe leaf } \\
\text { curling in upper bines }\end{array}$ & Japan & 161 \\
\hline $\begin{array}{l}\text { Hop infectious sterility (unknown virus } \\
\text { or viruslike agent) }\end{array}$ & Sterility & Poland & 203 \\
\hline
\end{tabular}


Certification programs for hops originated in the United Kingdom in 1943 with a program for the inspection and certification of hop yards for freedom from Verticillium wilt (52). This was a voluntary program run by the Ministry of Agriculture Fisheries and Food (MAFF) that awarded certificates to yards apparently free of wilt. The virus disease nettlehead was also included, but because it was so widespread it was only possible to set "a limit of very low percentage of virus infection" $(13,81)$. This allowed growers to obtain wilt-free planting material, usually as strap cuts from the rooted base of bines in commercial hop yards. In 1947, legislation in the form of the "Progressive Verticillium Wilt of Hops Order" was passed, making wilt a notifiable disease and prohibiting the sale of hop plants from infected yards. In 1949, grade A and B certificates were introduced in a program for the inspection of hop yards. Virus diseases were included in this, and a tolerance for nettlehead of $0.25 \%$ and mosaic of $2 \%$ was set for grade A plants. This was superseded by the A-plus program in 1955 , in which the propagation of pathogen-tested clones was undertaken by specialist propagators isolated from commercial wilt-infested areas.

The practice of growers taking sets at random from established yards during the dormant period was also important in pathogen dissemination to succeeding yards in Australia (197), and probably elsewhere. In 1950, the Department of Agriculture in Australia began the selection and maintenance of three hop cultivars free of virus symptoms for growers to obtain healthy material (197). Johnstone (78) correctly predicted that the future control of nettlehead lay in the production of virus-free (virus-tested) cultivars by heat therapy and meristem tip culture. The advent of mist propagation of softwood cuttings is also believed to have lowered the probability of plants with obvious symptoms being used for propagation purposes. However, apart from some effects of viruses on softwood cutting mortality (138), the spread of viruses causing latent infections or mild symptoms would have continued.

The increased knowledge of the damage due to latent virus infections led to the production of virus-tested clones by heat therapy and meristem tip culture in the United Kingdom in 1966. Vine and Jones (195) exposed plants for 2 to 4 weeks at $35^{\circ} \mathrm{C}$ and raised tips of up to $5 \mathrm{~mm}$ long in a culture media to obtain plants free of ApMV and HpMV, but not HpLV. They found that while excised tips of this size sometimes contained virus, the resulting plants were often virus-free. This indicated that the virus was sometimes eliminated during the culture procedure rather than through excision of virus-tested material. This suggested a balance between virus replication and degradation in the meristem which was pushed in favor of the latter during culture. Adams (1) also obtained ApMV-free plants by growing excised tips ( 1 to $5 \mathrm{~mm}$ ) from plants treated at $35^{\circ} \mathrm{C}$ for 10 days, but $\mathrm{HpMV}$ was not eliminated. However, removal of smaller meristems $(0.5 \mathrm{~mm})$ from plants that were not heat-treated did eliminate HpMV. Adams (2) used improved media to enable the culturing of smaller tips ( 0.3 to $0.8 \mathrm{~mm}$ long) than was achieved by Vine and Jones (195), and was able to obtain plants free of HpMV and HpLV without heat therapy. However, ApMV could only be consistently removed by the use of heat therapy. Tips ( 1 to $5 \mathrm{~cm}$ long) taken after 10 to 18 days at $35^{\circ} \mathrm{C}$ and 16 -h day length (and in one instance after only 3 days) developed into plants free of this virus. From 1969, cultivars were released in the United Kingdom free of ApMV and ArMV but still containing HpMV and HpLV. In 1970, some cultivars were released free of ArMV, ApMV, and HpMV, and by 1972 material free of all known viruses became available.

The A-plus program established in the United Kingdom began with the production of virus-tested plants by heat therapy and meristem culture (2). Four mother plants of each main cultivar were then grown on in isolation, and tested for the presence of virus at biennial intervals. Propagators in areas away from the commercial hop yards were supplied with cuttings which they used to establish layer beds for further propagation. These beds were used as parent stock for 10 years before renewal. The established layer beds were inspected twice each season and certified if they reached the required standard of health. Nurseries had to be established on soil tested to be free of $X$. diversicaudatum (44), and had to be at least 30 $\mathrm{km}$ away from areas with virulent Verticillium wilt. In addition, wilt-sensitive cultivars could not be grown on the same property as wilt-tolerant cultivars. Procedures such as using disinfectant footbaths, the wearing of special boots, and restricted vehicle entry were adopted to minimize the spread of soilborne pathogens and $X$. diversicaudatum. Plant indexing was conducting by serological testing and mechanical inoculation to Chenopodium quinoa and Cucumis sativus. The establishment of certification programs in the United Kingdom was primarily aimed at eliminating ArMV and ApMV. These viruses could be controlled by such a program because of their slow reinfection rates. Many countries, including the United States, Australia, South Africa, New Zealand, and most European countries, now produce virus-tested material as part of their plant propagation techniques.

Management of viruses within commercial yards. The most successful example of management of virus diseases of hop has been the control of ArMV-H by the institution of a fallow period followed by replanting with virus-tested material. Bare fallows of 12 to 18 months, 19 to 20 months, and 20 to 42 months led to reinfection of virus-tested hops of 13 to $24 \%$, 1 to $3 \%$, and $0 \%$, respectively $(7,8)$. Control was mainly through loss of transmissible virus from the nematode population rather than a direct effect on the vector population. In the United Kingdom, a 2year fallow period was recommended if the yard had a prior history of nettlehead or ArMV-H, irrespective of whether $X$. diversicaudatum had been detected in the yard, because the efficiency of transmission meant that even low numbers of nematodes could contribute to spread. By contrast, growers were recommended to plant virus tested stock immediately if there had been no evidence of nettlehead or ArMV-H in the yard irrespective of the presence of $X$. diversicaudatum because the nematode population was likely to be nonviruliferous (189). This strategy required careful removal of rogue hops as a source of ArMV-H. Only one full crop would be lost if plants were removed directly after harvest and mist-propagated plants or cold stored sets were planted $(8,61,106)$. Nettlehead, barebine, and split leaf blotch were common in hop yards in the United Kingdom until the 1970s, at which time virus-tested material became available through the A-plus program. These diseases are no longer considered limiting to production in the United Kingdom. Many other countries have also adopted high-health programs that have markedly reduced the incidence of ArMV$\mathrm{H}$ and its impact on hop yield. The use of nematicides to reduce ArMV-H spread into virus-tested material has had limited success. Pitcher and McNamara (142) reported a 95 to $100 \%$ reduction in populations of $X$. diversicaudatum in the 15 to 30 $\mathrm{cm}$ zone in the first year after application of DD (1,3-dichloropropene). However, by the fourth year after replanting with healthy stock, the incidence of ArMV-H was $80 \%$. The lack of efficacy of chemical control has been attributed to the inability of nematicides to penetrate through the heavy soils to depths that hop roots and vector nematodes can penetrate and to the efficiency of transmission by low vector population densities.

Similarly, vector control for carlavirus spread is not economically feasible. Insecticide sprays to control populations of $P$. humuli are frequently used in regions where the aphid is prevalent, but this aims to reduce the damage from insect feeding and is not effective in reducing nonpersistent carlavirus transmission. For the carlaviruses, ApMV, and all viroids, minimizing contact between plants will also significantly reduce within-yard spread. For example, reducing basal growth contact between plants in early spring reduced the 
spread of ApMV to adjacent plants by almost half (131).

Management of viroids. The discovery of widespread infections of HpLVd led to efforts to eliminate this pathogen from hop. Meristem tip culture $(71,129)$, thermotherapy (100), and cold treatment (111) have been found to significantly reduce viroid titer. Hataya et al. (71) were successful at eliminating $\mathrm{HpLVd}$ from in fected material of two hop cultivars by excising tips of $0.2 \mathrm{~mm}$ in size. Moreover, culturing of tips of $0.5 \mathrm{~mm}$ in size was successful at regenerating shoots free of HpLVd when selected in May and early June, when viroid titer was low (129). Cold treatment conditions found to be optimal for producing plants free of HpLVd were storage at 2 to $4{ }^{\circ} \mathrm{C}$ in the dark for periods ranging from 8 to 21 months, and subsequent meristem culture of tips less than $0.5 \mathrm{~mm}$ in size (111). Optimal thermotherapy conditions were exposure to $36^{\circ} \mathrm{C}$ for 14 days; however, original titers were restored after 6 months in field conditions (100). The rapid decrease in HpLVd levels following heat treatment was correlated with the induction of a nucleolytic complex which resulted in cleaving of the viroid (100). Heat treat-

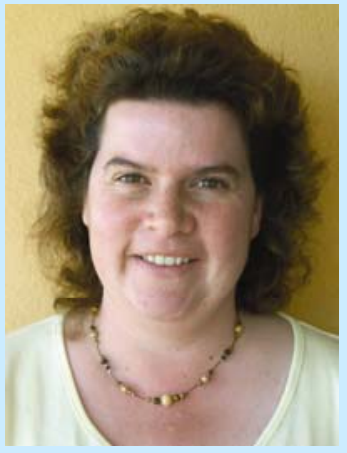

Sarah J. Pethybridge

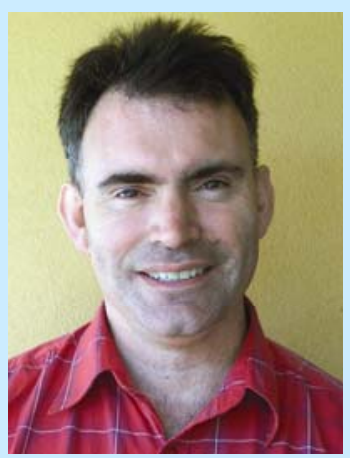

Frank S. Hay

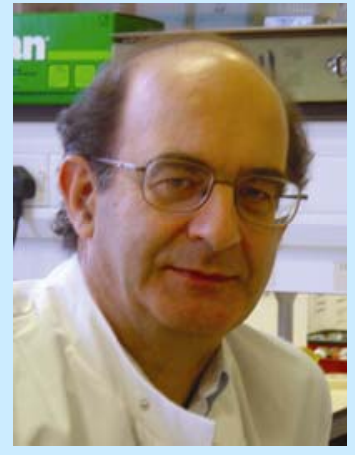

Dez J. Barbara

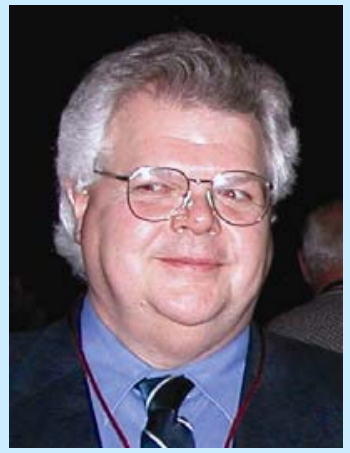

Kenneth C. Eastwell

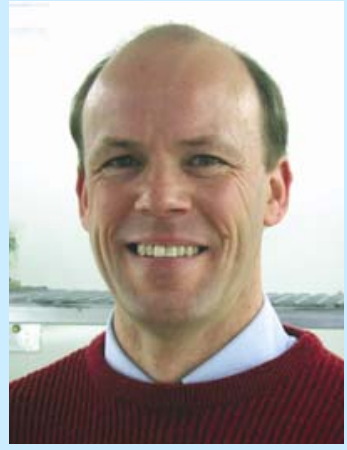

Calum R. Wilson
Dr. Pethybridge is a research plant pathologist with the Tasmanian Institute of Agricultural Research (TIAR) at the University of Tasmania's Cradle Coast campus in Burnie, Tasmania, Australia. She completed her undergraduate degree in Agricultural Science with First Class Honours and Doctor of Philosophy degree in plant pathology at the University of Tasmania in Hobart. Her Ph.D. dissertation examined the epidemiology and management of viruses infecting hop in Australia. Her research program focuses on the epidemiology and management of hop and pyrethrum diseases.

Dr. Hay is the leader of the Vegetable Research Group within TIAR, and is based at the University of Tasmania's Cradle Coast campus in Burnie. He completed his Bachelor of Horticultural Science degree with First Class Honours and Doctor of Philosophy degree in plant pathology at Lincoln University in Christchurch, New Zealand. His Ph.D. dissertation was entitled "Studies on the Viruses of Hop in New Zealand". Dr. Hay's research program focuses on the integrated management of diseases of vegetables.

Dr. Barbara is a research leader at Warwick HRI on the Wellesbourne campus of Warwick University in the United Kingdom. After obtaining a Bachelor of Science in biological sciences and a Doctor of Philosophy degree for studies on Cucumber mosaic virus (both from the University of Birmingham, UK), Dr. Barbara worked on virus and viroid diseases of fruit and hop at East Malling Research Station. His interests then broadened to cover other pathogens, and at present his primary focus is on understanding soilborne fungal diseases.

Dr. Eastwell is an associate scientist in the Department of Plant Pathology at the Prosser Irrigated Agriculture Research and Extension Center of Washington State University. Dr. Eastwell obtained his Bachelor of Science with First Class Honours in biochemistry and his Doctor of Philosophy degree in plant biochemistry from the University of Alberta in Edmonton. His research interests have included plant metabolism and protein chemistry. Current research activity focuses on the characterization and management of virus diseases of perennial fruit crops and hop.

Dr. Wilson is an associate professor of plant pathology within TIAR, and is located at the University of Tasmania's New Town Research Laboratories in Hobart. Dr. Wilson obtained his Bachelor of Science with Honours and Master of Science with Distinction, from the University of Canterbury in Christchurch, New Zealand, and his Doctor of Philosophy degree from the University of Western Australia in Perth. His research portfolio is diverse with work across a range of plant pathogens and hosts, but focuses host-pathogen interactions, resistance mechanisms and genetics, epidemiology, and disease management. 
ment also led to the accumulation of sequence variants in the HpLVd population. Despite prediction of destabilizing the secondary structure of HpLVd from these mutations, all mutated cDNAs were found to be infectious to hop and evolved into complex progeny populations containing molecular variants maintained at low levels (99).

The management of viroids requires quick identification and removal of infected plants to prevent further spread. The absence of symptoms associated with $\mathrm{HpLVd}$, and the long latent period before visible symptoms of $\mathrm{HpSVd}$ and Apple fruit crinkle viroid (AFCVd) develop, challenge the ability to contain these viroids. Effective roguing requires the infected plant and several plants adjacent both along and across rows to be removed $(161,162,201)$. Although partial replanting following removal of diseased and buffer plants can be effective, better control has been achieved by removal of all plants in a yard, followed by replanting with certified material. Roguing for viroid infection required all plants to be destroyed by treating with urea and chloropicrin in autumn to ensure the disease was not carried over to the succeeding crop (162). $\mathrm{HpSVd}$ can be found in hop residue; however, leaves and cones were found to lose their infectivity after 3 months under normal field conditions (177). In conjunction with roguing, reducing agronomic operations of a mechanical nature which may contribute to $\mathrm{HpSVd}$ spread within and between yards will also be beneficial (162). In areas containing infected plants and where mechanical operations are essential, disinfecting equipment for 10 minutes in either formaldehyde, sodium hydroxide, sodium or calcium hypochlorite, or trisodium phosphate has also been demonstrated to be effective at reducing HpSVd spread (162,176,177). Heating blades at $160^{\circ} \mathrm{C}$ for 10 min was also effective, but $140^{\circ} \mathrm{C}$ was not. These measures have seen the virtual elimination of $\mathrm{HpSVd}$ from the Kirin Brewery yards in Japan (162). Therefore, the three central pieces to the HpSVd control program in Japan are in most ways similar to every viroid control program, regardless of host. These include making and utilizing certified viroid-free material, identification and prompt roguing of viroid-infected plants, and sanitation of farm equipment between yards. However, after 30 years of aggressive action, these practices have failed to eliminate HpSVd but have effectively minimized the deleterious effects of the pathogen on production.

\section{Acknowledgments}

We thank the financial supporters of our respective hop pathology programs including Hop Products Australia and the Australian Research Council, the New Zealand Hop Marketing Committee, in the UK the Biotechnology and Biological Sciences Research Council and the Department for the Envi- ronment Food and Rural Affairs, and in the United States the Hop Research Council and the Washington Hop Commission. We also thank our collaborators (Larry Madden, Ohio State University; Frank Ferrandino, Connecticut Agricultural Experiment Station, S. Nelson, Cooperative Extension Service, University of Hawaii, Hilo, HI; Mark Nelson, Washington State University at Prosser, WA). Special thanks to David Gent (U.S. Department of Agriculture - Agricultural Research Service, Corvallis, OR) for providing Figures 1 and 6, and J. M. Thresh for Figure 5A, B, and D. We also extend our thanks for the excellent technical support we have received, the contributions of many other participants in our respective national programs, and the support of growers, trade and hop user groups in the various countries.

\section{Literature Cited}

1. Adams, A. N. 1972. Virus diseases of hop Production of virus-free hop plants. Rep. East Malling Res. Stn. 1971:123-124.

2. Adams, A. N. 1973. Viruses latent in hop (Humulus lupulus L.) and techniques for obtaining virus-free clones. Pages 431-435 in: Proc. Br. Insect. Fung. Conf. 7th.

3. Adams, A. N., and Barbara, D. J. 1980. Host range, purification, and some properties of hop mosaic virus. Ann. Appl. Biol. 96:201-208.

4. Adams, A. N., and Barbara, D. J. 1982. Host range, purification and some properties of two carlaviruses from hop (Humulus lupulus): Hop latent and American hop latent. Ann. Appl. Biol. 101:483-494

5. Adams, A. N., Barbara, D. J., and Clark, M. F. 1982. The occurrence and some properties of three carlaviruses infecting hop plants $(\mathrm{Hu}$ mulus lupulus) in England. Acta Hortic. 130:243-247.

6. Adams, A. N., Barbara, D. J., Clark, M. F., and Davies, D. L. 1986. Association of arabis mosaic virus with hop chlorotic disease. Acta Hortic. 193:59-60.

7. Adams, A. N., Barbara, D. J., Clark, M. F., Flegg, C. L., and Thresh, J. M. 1977. Virus diseases of hop. Rep. East Malling Res. Stn. 1976:147.

8. Adams, A. N., Barbara, D. J., Clark, M. F., Manwell, W. F., and Thresh, J. M. 1978. Virus diseases of hop. Rep. East Malling Res. Stn. 1977:102-103.

9. Adams, A. N., Barbara, D. J., and Davies, D. L. 1987. The etiology of hop chlorotic disease. Ann. Appl. Biol. 111:365-371.

10. Adams, A. N., Barbara D. J., and Morton, A. 1991. Effects of hop latent viroid on weight and quality of the cones of the hop cultivar Wye Challenger. Ann. Appl. Biol. 118(Suppl.): 126-127.

11. Adams, A. N., Barbara, D. J., Morton, A., and Darby, P. 1996. The experimental transmission of hop latent viroid and its elimination by low temperature treatment and meristem culture. Ann. Appl. Biol. 128:37-44.

12. Adams, A. N., Clark, M. F., and Barbara, D. J. 1989. Host range, purification and some properties of a new ilarvirus from Humulus japonicus. Ann. Appl. Biol. 114:497-508.

13. Adams, A. N., Darby, P., and Ebbels, D. L. 1989. Production and distribution of virustested hops in the U.K. Pages 127-130 in: Proc. Int. Workshop Hop Virus Dis. Giessen.

14. Adams, A. N., Morton, A., Barbara, D. J., and Ridout, M. S. 1992. The distribution and spread of hop latent viroid within two commercial plantings of hop (Humulus lupulus). Ann. Appl. Biol. 121:585-592.

15. Albrechtova, L., Chod, J., Kriz, J., and Fencl, J. 1979. Nachweis des Apple mosaic virus und des Tobacco necrosis virus in Hopfen. Phytopathol. Z. 94:45-55.

16. Alfaro, A., and Goheen, A. C. 1974. Transmission of strains of grapevine fan leaf virus by Xiphinema index. Plant Dis. Rep. 58:549552 .

17. Anonymous. 1976. The breeding and development of new hop varieties - Diseases. Page 30 in: Proc. Sc. Comm. Int. Hop Growers Conven. Wye.

18. Anonymous. 2001. Xiphinema diversicaudatum. Distribution Maps of Plant Diseases (October (Edition 1)): Map 846. CAB International, UK.

19. Astruc, N., Marcos, J. F., Macquaire, G., Candresse, T., and Pallás, V. 1996. Studies on the diagnosis of hop stunt viroid in fruit trees: Identification of new hosts and application of a nucleic acid extraction procedure based on non-organic solvents. Eur. J. Plant Pathol. 102:837-846.

20. Barbara, D. J., and Adams, A. N. 1981. Hop mosaic virus. CMI/AAB Descriptions of Plant Viruses, No. 241.

21. Barbara, D. J., and Adams, A. N. 1983. Hop latent virus. CMI/AAB Descriptions of Plant Viruses, No. 261.

22. Barbara, D. J., and Adams, A. N. 1983. American hop latent virus. CMI/AAB Descriptions of Plant Viruses, No. 262.

23. Barbara, D. J., Clark, M. F., Thresh, J. M., and Casper, R. 1978. Rapid detection and serotyping of prunus necrotic ringspot virus in perennial crops by enzyme-linked immunosorbent assay. Ann. Appl. Biol. 90:395-399.

24. Barbara, D. J., Morton, A., and Adams, A. N. 1990. Assessment of UK hops for the occurrence of hop latent and hop stunt viroids. Ann. Appl. Biol. 116:265-272.

25. Barbara, D. J., Morton, A., Adams, A. N., and Green, C. P. 1990. Some effects of hop latent viroid on two cultivars of hop (Humulus lupulus) in the UK. Ann. Appl. Biol. 117:359-366.

26. Barth, H. J., and Haas, J. I. 2006. The Barth Report: Hops 2005/06. Joh. Barth \& Sohn, Nuremberg, Germany.

27. Bock, K. R. 1966. Arabis mosaic and Prunus necrotic ringspot viruses in hop (Humulus lupulus L.). Ann. Appl. Biol. 57:131-140.

28. Bock, K. R. 1967. Strains of prunus necrotic ringspot virus in hop (Humulus lupulus L.) Ann. Appl. Biol. 59:437-446.

29. Bock, K. R. 1967. Hop mosaic virus. Rep. East Malling Res. Stn. 1966:163-165.

30. Brown, D. F. J. 1975. Short report: Geographical distribution of Xiphinema and Longidorus in the British Isles. Pages 349 350 in: Nematode Vectors of Plant Viruses. F. Lamberti, C. E. Taylor, and J. W. Seinhorst, eds. NATO Advanced Study Institute Series, Vol. 2. Plenum Press, London, UK.

31. Brown, D. F. J., and Coiro, M. I. 1983. The total reproductive capacity and longevity of individual female Xiphinema diversicaudatum (Nematoda: Dorylaimida). Nematol. Mediterr. 11:87-92.

32. Burgess, A. H. 1964. Hops: Botany, Cultivation and Utilization. World Crop Books, Interscience Publication, New York.

33. Cadman, C. H. 1963. Affinities of viruses infecting fruit trees and raspberry. Plant Dis. Rep. 47:459-462.

34. Campbell, C. A. M. 1977. Distribution of damson-hop aphid (Phorodon humuli) migrants on hops in relation to hop variety and wind shelter. Ann. Appl. Biol. 87:315-325.

35. Campbell, C. A. M., and Cone, W. W. 1994. Influence of predators on population development of Phorodon humuli (Homoptera: Aphididae) on hops. Environ. Entomol. 23:13911396.

36. Cartledge, E. G. 1956. An investigation into the diseases of Tasmanian hops. Tas. J. Agric. 27:210-219

37. Casper, R. 1983. ELISA detection of ilarviruses in fruit trees by antisera having strong heterologous reactions. Acta Hortic. 130:143144. 
38. Chambers, D. A., Hignett, R. C., Carder, J. H., Marks, M. J., Adams, A. N., and Blake, V. S. A. 1986. Diseases of hop. Rep. East Malling Res. Stn. 1985:137-140.

39. Chod, J., Jokes, M., and Novak, M. 1979. The electron-microscopic proof of Tobacco necrosis virus in hop plants. Biol. Plant. 21:152153.

40. Chod, J., Polak, J., Novak, M., and Kriz, J. 1974. Occurrence of Mycoplasma-like organisms in hop cones with necrotic crinkle mosaic. Phytopathol. Z. 80:54-59.

41. Clark, M. F. 1975. Virus diseases of hop. Rep. East Malling Res. Stn. 1974:124.

42. Clark, M. F., Flegg, C. L., and Bates, D. 1979. Hop nettlehead disease. Rep. East Malling Res. Stn. 1978:100-101.

43. Cotton, J. 1977. Effect of annual and perennial cropping regimes in microplots on the population density and vertical distribution of Xiphinema diversicaudatum and on soil porosity. Ann. Appl. Biol. 86:397-404.

44. Cotton, J. 1979. The effectiveness of soil sampling for virus-vector nematodes in MAFF certification schemes for fruit and hops. Plant Pathol. 28:40-44.

45. Crosslin, J. M., and Mink, G. I. 1992. Biophysical differences among Prunus necrotic ringspot ilarviruses. Phytopathology 82:200206.

46. Crowle, D. R., Pethybridge, S. J., Leggett, G. W., Sherriff, L. J., and Wilson, C. R. 2003. Diversity of the coat protein-coding region among Ilarvirus isolates infecting hop in Australia. Plant Pathol. 52:655-662.

47. Crowle, D. R., Pethybridge, S. J., and Wilson, C. R. 2006. Transmission of hop latent and hop mosaic carlaviruses by Macrosiphum euphorbiae and Myzus persicae. J. Phytopathol. 154:745-747.

48. Dale, C. J., and Shardlow, J. A. 1986. Hops and foam lacing. English Hops (May):5.

49. Darby, P. 1999. New selection criteria for hop breeding. Pages 3-6 in: Proc. Sc. Comm. Int. Hop Grow. Convn. Pulawy.

50. Davies, D. L., and Clark, M. F. 1983. A satellite-like nucleic acid of arabis mosaic virus associated with hop nettlehead disease. Ann. Appl. Biol. 103:439-448.

51. Davies, D. L., and Clark, M. F. 1989. Detection and occurrence of additional nucleic acid species associated with hop isolates of arabis mosaic virus. Pages 61-68 in: Proc. Int. Workshop Hop Virus Dis. Giessen.

52. Ebbels, D. L. 1979. A historical review of certification schemes. ADAS Quart. Rev., MAFF 32:21-58.

53. Eppler, A. 1983. Transmission of hop viruses and the role of wild and escaped hops as sources of virus spread. Med. Fac. Landbouww. Rijksuniv. Gent. 48:883-892.

54. Eppler, A. 1989. Presence of viruses in the hop growing region of Alsace (France). Page 209 in: Proc. Int. Workshop Hop Virus Dis. Giessen.

55. Eppler, A. 1989. Sensitivity, tolerance and resistance in the hop - CARLA-virus relationship. Pages 99-108 in: Proc. Int. Workshop Hop Virus Dis. Giessen.

56. Eppler, A. 1989. Settling behaviour of Phorodon humuli in relation to virus spread. Pages 113-119 in: Proc. Int. Workshop Hop Virus Dis. Giessen.

57. Eppler, A. 1990. Elimination of American hop latent virus (AHLV) from hops. Med. Fac. Landbouww. Rijksuniv. Gent. 55:1055-1057.

58. Eppler, A. 1994. Ecology of aphids on hops and its significance on spread of hop viruses. Z. Pflanzenkr. Pflanzenschutz 102:2-15.

59. Eppler, A. 2001. Virus-infections of wild hops in Hamburg. Med. Fac. Landbouww. Rijksuniv. Gent. 66:133-138.

60. Eppler, A., and Dahdahbiglou, R. 1991. Experiments on the non-vectorial transmission of PNRV in hops. Med. Fac. Landbouww. Rijksuniv. Gent. 56:577-587.

61. Eppler, A., Rindfleisch, I., and McNamara, D. G. 1989. Soil management-dependent occurrence of Xiphinema diversicaudatum and Longidorus spp. in and around hop gardens. Page 201 in: Proc. Int. Workshop Hop Virus Dis. Giessen.

62. Flegg, J. J. M., Baxendal, M., and Popham, A. M. 1970. Reproductive potential of Xiphinema diversicaudatum on strawberry. Nematology $16: 398-402$

63. Fonseca, M. E. N., Marinho, V. L. A., and Nagata, T. 1993. Hop latent viroid in hop germ plasm introduced into Brazil from the United States. Plant Dis. 77:952.

64. Fridlund, P. R. 1959. A latent virus of hops detected by cucumber inoculation. Plant Dis. Rep. 43:594

65. Fulton, R. W. 1968. Serology of viruses causing cherry necrotic ringspot, plum line pattern, and apple mosaic. Phytopathology 58:635-638.

66. Greber, R. S., Klose, M. J., Milne, R. S., and Teakle, D. S. 1991. Transmission of prunus necrotic ringspot virus using plum pollen and thrips. Ann. Appl. Biol. 118:589-593.

67. Greber, R. S., Teakle, D. S., and Mink, G. I. 1992. Thrips-facilitated transmission of prune dwarf and prunus necrotic ringspot viruses from cherry pollen to cucumber. Plant Dis. 76:1039-1041.

68. Harrison, B. D. 1967. The transmission of strawberry latent ringspot virus by Xiphinema diversicaudatum. Ann. Appl. Biol. 60:405409.

69. Harrison, B. D., and Winslow, R. D. 1961. Laboratory and field studies on the relation of AMV to its nematode vector Xiphinema diversicaudatum. Ann. Appl. Biol. 49:621-633.

70. Hataya, T., Arimoto, R., Suda, N., and Uyeda, I. 2001. Molecular characterisation of Hop mosaic virus: Its serological and molecular relationships to Hop latent virus. Arch. Virol. 146:1935-1948.

71. Hataya, T., Hikage, K., Sunda, N., Nagata, T., Li, S., Itoga, Y., Tanikoshi, T., and Shikata, E. 1992. Detection of hop latent viroid (HLVd) using reverse transcription and polymerase chain reaction (RT-PCR). Ann. Phytopathol. Soc. Jpn. 58:677-684.

72. Hataya, T., Uchino, K., Arimoto, R., Suda, N., Sano, T., Shikata, E., and Uyeda, I. 2000. Molecular characterisation of Hop latent virus and phylogenic relationships among viruses closely related to carlaviruses. Arch. Virol. 145:2503-2524.

73. Hay, F. S. 1989. Studies on the viruses of hop (Humulus lupulus L.) in New Zealand. Ph.D. thesis. Lincoln University, Christchurch, New Zealand.

74. Hay, F. S., and Close, R. C. 1992. Distribution of Xiphinema diversicaudatum (Micoletzky, 1927) Thorne, 1939 in commercial hop ( $\mathrm{Hu}$ mulus lupulus L.) gardens in New Zealand and implications for the spread of arabis mosaic virus. N.Z. J. Crop Hortic. Sci. 20:367370

75. Hay, F. S., Close, R. C., and Beatson, R. 1989. The effect of virus infections on the yield and alpha/beta-acid content of the hop variety Superalpha. Pages 137-148 in: Proc. Int. Workshop Hop Virus Dis. Giessen.

76. Hay, F. S., Close, R. C., Fletcher, J. D., and Ashby, J. W. 1992. Incidence and spread of viruses in hop (Humulus lupulus L.) in New Zealand. N.Z. J. Crop Hortic. Sci. 20:319327.

77. Hoerner, G. R. 1949. Hop diseases in the United States. Brewers' Digest 24:45-51.

78. Johnstone, G. R. 1965. Hop nettlehead Field spread and effect on yield. Tas. J. Agric. 36:277-279

79. Kanno, Y., Yoshikawa, N., and Takahashi, T.
1993. Some properties of hop latent and apple mosaic viruses isolated from hop plants and their distributions in Japan. Ann. Phytopathol Soc. Jpn. 59:651-658.

80. Kaper, J. M., Tousignant, M. E., and Steger, G. 1988. Ribonucleotide sequence predicts circularity and self-cleavage of 300-ribonucleotide satellite of arabis mosaic virus. Biochem. Biophys. Res. Comm. 154: 318-325.

81. Keyworth, W. G. 1945. Three important hop diseases. J. Min. Agric. 51:556-561

82. Keyworth, W. G., and Davies, D. L. G. 1946. Nettlehead disease of the hop (Humulus lupulus). J. Pomol. Hortic. Sci. 22:134-139.

83. Klein, R. E., and Husfloen, S. D. 1995. Incidence of five viruses in hop (Humulus lupulus L.) in the Pacific Northwest. Plant Dis 79:425.

84. Knabel, Von S., Seigner, L., and Wallnofer, P. R. 1999. Detection of hop latent viroid (HLVd) using the polymerase chain reaction (PCR). Gesunde Pflanzen 51:234-239.

85. Knapic, V., and Javornik, B. 1998. ViroidiPovročitelji Rastlinskih Bolezni. Sodobno Kmetijstvo 31:462-465.

86. Koltunow, A. M., Krake, L. R., and Rezaian, M. A. 1988. Hop stunt viroid in Australia grapevine cultivars: Potential for hop infection. Aust. Plant Pathol. 17:7-9.

87. Kremheller, H. T., Rossbauer, G., and Ehrmaier, H. 1989. Reinfection of virus-free planted hop gardens with Prunus necrotic ringspot and hop mosaic virus. Effects of the virus infection upon the yield, alpha acids, and the disease symptoms of the various hop varieties. Pages 133-136 in: Proc. Int. Workshop Hop Virus Dis. Giessen.

88. Lafontaine, D. A., Deschenes, P., Bussiere, F. Poisson, V., and Perreault, J.-P. 1999. The viroid and viroid-like RNA database. Nucleic Acids Res. 27:186-187.

89. Lee, J. Y., Lee, S. H., and Sänger, H. L. 1990. Viroid diseases occurring on Korean hop plants. Korean J. Plant Pathol. 6:256-260.

90. Legg, J. T. 1959. The effect of split leaf blotch and nettlehead virus diseases on the yield of Fuggle hops. J. Hortic. Sci. 34:122 125.

91. Legg, J. T. 1965. Mechanical transmission of hop mosaic virus. Nature 208:1017-1018.

92. Legg, J. T., and Ormerod, P. J. 1959. Research on hop virus diseases at East Malling. Rep. East Malling Res. Stn. 1958:157-160.

93. Legrand, G., and Maroquin, C. 1989. Health improvement of the hop grown in Belgium and use of virus-free material. Pages 123-126 in: Proc. Int. Workshop Hop Virus Dis. Giessen

94. Mackenzie, D., Salmon, E. S., Ware, W. M. and Williams, R. 1929. The mosaic disease of the hop. Ann. Appl. Biol. 16:359-381.

95. Macovei, A. 1979. Identificarea si stabilirea principalelor characteristici ale virusurilor hameiului in Romania. III. Identificarea si characterizarea unie noi boli virotice si a agentului sau cauzal. Anal. ICPP. 15:37-41.

96. Macovei, A. 1981. Identificarea si stabilirea principalelor characteristici ale virusurilor hameiului in Romania. IV. Unele dataprivind prezenta virusului mozaicului castravetilor la soiul de hamei Huller Bitter. Anal. ICPP 16:47-51.

97. Macovei, A. 1988. A survey of the Romanian virus diseases and the electronmicroscopial characterization of the viruses involved Pages 19-22 in: Proc. Int. Workshop Hop Virus Dis. Giessen.

98. Matoušek, J., and Patzak, J. 2000. A low transmissibility of hop latent viroid (HLVd) through a generative phase of hop (Humulus lupulus L.). Biol. Plant 43:145-148.

99. Matoušek, J., Patzak, J., Orctová, L., Schubert, J., Vrba, L., Steger, G., and Riesner, D 2001. The variability of hop latent viroid as 
induced upon heat treatment. Virology 287:349-358

100. Matousek, J., Trnena, L., Svoboda, P., Oriniaková, P., and Lichtenstein, C. P. 1995. The gradual reduction of viroid levels in hop mericlones following heat therapy. A possible role for a nuclease degrading dsRNA. Biol. Chem. Hoppe-Seyler 376:715-721.

101. Matousek, J., Trnena, L., Svoboda, P., and Ruzkova, P. 1994. Analysis of hop latent viroid (HLVd) in commercial hop clones in Czech Republic. Rost. Vyr. 40:973-983.

102. McNamara, D. G. 1980. The survival of Xiphinema diversicaudatum in plant free soil. Nematology 26:170-181.

103. McNamara, D. G. 1980. The spread of arabis mosaic virus through non-cultivated vegetation. Plant Pathol. 29:173-176.

104. McNamara, D. G., and Eppler, A. 1989. The Longidoridae occurring in the German hopgrowing regions. Page 195 in: Proc. Int. Workshop Hop Virus Dis. Giessen.

105. McNamara, D. G., and Eppler, A. 1989. Arabis mosaic virus and Xiphinema diversicaudatum in German hops. Page 198 in: Proc. Int. Workshop Hop Virus Dis. Giessen.

106. McNamara, D. G., Ormerod, P. J., Pitcher, R. S., and Thresh, J. M. 1973. Fallowing and fumigation experiments on the control of nettlehead and related virus diseases of hops. Pages 597-602 in: Proc. Br. Insect. Fung. Conf. 7th.

107. McNamara, D. G., and Pitcher, R. S. 1974. The control of arabis mosaic virus by soil fumigation and fallowing. Agro-Ecosys. 1:123129.

108. Menary, R. C., and Doe, P. E. 1983. Some morphological and chemical changes in hops during maturation. J. Sci. Food Agric. 34:921929.

109. Mink, G. I. 1992. Prunus necrotic ringspot virus. In: Plant Diseases of International Importance, vol. III. Diseases of Fruit Crops. R. Kumar, H. S. Chaube, U. S. Singh, and A. N. Mukhopadhyay, ed. Prentice-Hall, Englewood Cliffs, NJ

110. Momma, T., and Takahashi, T. 1984. Developmental morphology of hop stunt viroid-infected hop plants and analysis of their cone yield. Phytopathol. Z. 110:1-14.

111. Morton, A., Barbara, D. J., and Adams, A. N. 1993. The distribution of hop latent viroid within plants of Humulus lupulus and attempts to obtain viroid-free plants. Ann. Appl. Biol. 123:47-53.

112. Munro, D. 1987. Viruses infecting hop, $H u$ mulus lupulus L. in Australia. Aust. J. Agric. Res. 38:83-90.

113. Munro, D. 1989. Spread of hop latent and hop mosaic virus in the absence of Phorodon humuli. Pages 109-112 in: In: Proc. Int. Workshop Hop Virus Dis. Giessen.

114. Murant, A. F. 1970. Arabis mosaic virus. CMI/AAB Descriptions of Plant Viruses No. 16.

115. Nelson, M. E., Klein, R. E., and Skrzeczkowski, L. J. 1998. Occurrence of hop latent viroid (HLVd) in hops in Washington State. (Abstr.) Phytopathology 88:S108.

116. Neve, R. A. 1979. Hop diseases: The risks and consequences of spread in a vegetatively propagated crop. Pages 155-161 in: Plant Health - The Scientific Basis for Administrative Control of Plants Diseases and Pests. D. L. Ebbels and J. E. King, eds. Blackwell Scientific, Oxford.

117. Neve, R. A. 1991. Hops. Chapman and Hall, London.

118. Neve, R. A., and Lewis, G. K. 1975. Plant Breeding Section, The Year's Work. Wye College Dep. Hop Res. Ann. Rep. 1974:6-8.

119. Neve, R. A., and Lewis, G. K. 1977. Plant Breeding Section, The Year's Work. Wye College Dep. Hop Res. Ann. Rep. 1976:7-9.

120. Neve, R. A., and Thresh, J. M. 1984. Prunus necrotic ringspot virus in hops. Eng. Hops (May):6-7

121. Novak, J. B., and Lanzova, J. 1976. Identification of Alfalfa mosaic virus and Tomato bushy stunt virus in hop (Humulus lupulus L.) and grapevine (Vitis vinifera subsp. sativa (DC./Hegi) plants in Czechoslovakia. Biol. Plant. 18:152-154

122. Ogilvie, L. 1939. Nettlehead disease of hops in the Bristol province. J. South Eastern Agric. Coll. Wye, Kent 44:44-46.

123. Ohno, T., Takamatsu, N., Meshi, T., and Okada, Y. 1983. Hop stunt viroid: Molecular cloning and nucleotide sequence of the complete cDNA copy. Nucleic Acids Res. 11:6185-6197.

124. Otter, G. E., and Taylor, L. 1978. The high performance liquid chromatography of hop resins. J. Inst. Brew. 84:160-164.

125. Paine, J. 1953. Insect vector studies with mosaic and other virus diseases of the hop. Rep. East Malling Res. Stn. 1952:120-123.

126. Paine, J., and Legg, J. T. 1953. Transmission of hop mosaic by Phorodon humuli (Schrank). Nature 171:263-264.

127. Palamand, S. R., and Aldenhoff, J. M. 1973. Tasting compounds of beer: Chemistry and taste properties of some hop compounds. J. Agric. Food Chem. 21:535-543.

128. Pallas, V., Navarro, A., and Flores, R. 1987. Isolation of a viroid-like RNA from hop different from hop stunt viroid. J. Gen. Virol. 68:3201-3205

129. Patzak, J., and Matoušek, J. 1999. The elimination of hop latent viroid (HLVd) infection by meristem in vitro culture of hop. Pages 124-129 in: Proc. Sc. Comm. Int. Hop Grow. Convn. Pulawy.

130. Patzak, J., Matoušek, J., Krofta, K., and Svoboda, P. 2001. Hop latent viroid (HLVd)caused pathogenesis: Effects of HLVd infection on lupulin composition of meristem culture-derived Humulus lupulus. Biol. Plant. 44:579-585.

131. Pethybridge, S. J. 2005. Epidemiology and management of viruses of hop in Australia. Acta Hortic. 668:131-142.

132. Pethybridge, S. J., Hay, F. S., Wilson, C. R., Leggett, G. W., and Sherriff, L. J. 2002. Mechanical transmission of Apple mosaic ilarvirus in Australian hop gardens. Ann. Appl. Biol. 141:77-85.

133. Pethybridge, S. J., and Madden, L. V. 2003. Analysis of spatiotemporal dynamics of virus spread in an Australian hop garden by stochastic modeling. Plant Dis. 87:56-62.

134. Pethybridge, S. J., Madden, L. V., Griggs, J., and Wilson, C. R. 2004. Species composition and abundance of aphids in Australian hop gardens and their impact on spatiotemporal patterns of carlavirus epidemics. Plant Pathol. 53:493-507.

135. Pethybridge, S. J., Nelson, M. E., Eastwell, K. C., Klein, R. E., Kenny, S. T., and Wilson, C. R. 2002. Incidence and spatial distribution of viruses in hop gardens of Washington State. Plant Dis. 86:661-665.

136. Pethybridge, S. J., and Turechek, W. W. 2003. Analysis of the association among three viruses infecting hop in Australia. Plant Pathol. 52:158-167.

137. Pethybridge, S. J., Wilson, C. R., Ferrandino, F. J., and Leggett, G. W. 1999. Spatial analysis of viral epidemics in Australian hop gardens: Implications for mechanisms of spread. Plant Dis. 84:513-515.

138. Pethybridge, S. J., Wilson, C. R., Hay, F. S., Leggett, G. W., and Sherriff, L. J. 2002. Effect of viruses on agronomic and brewing characteristics of four hop (Humulus lupulus L.) cultivars in Australia. Ann. Appl. Biol. 140:97-105

139. Pethybridge, S. J., Wilson, C. R., and Leggett, G. W. 2004. Incidence and effect of viruses on production of two newly adopted hop $(\mathrm{Hu}$ mulus lupulus) cultivars in Australia. Aust. J. Agric. Res. 55:765-770.

140. Pethybridge, S. J., Wilson, C. R., Sherriff, L. J., Leggett, G. W., and Munro, D. 2000. Virus incidence in Australian hop (Humulus lupulus L.) gardens and cultivar differences in susceptibility to infection. Aust. J. Agric. Res 51:685-689.

141. Pichlmaier, J. 1989. Investigations on the association of viruses with hop root-rot. Pages 193-194 in: Proc. Int. Workshop Hop Virus Dis. Giessen.

142. Pitcher, R. S., and McNamara, D. G. 1973. The control of Xiphinema diversicaudatum, the vector of arabis mosaic virus in hops Ann. Appl. Biol. 75:468-469.

143. Pitcher, R. S., Siddiqi, M. R., and Brown, D. F. J. 1974. Xiphinema diversicaudatum C.I.H. Descriptions of Plant-Parasitic Nematodes (Set 4, No. 60)

144. Polak, J. 1996. Distribution of hop mosaic virus in hop gardens of the Czech Republic. Ochr. Rostl. 32:9-14.

145. Polak, J., and Svoboda, P. 1989. Preliminary results of screening hop varieties and clones for the presence of some hop viruses in Czechoslovakia using ELISA. Pages 27-31 in: Proc. Int. Workshop Hop Virus Dis. Giessen.

146. Poll, J. 1986. New crops, hop shoots. South. Hortic. (April): 15

147. Probasco, E. G., and Murphey, J. M. 1996. The effects of hop viruses on brewing and agronomic characteristics in the hop variety Chinook. MBAA Tech. Quart. 33:160-165.

148. Probasco, E. G., and Skotland, C. B. 1976. A technique for differential isolation of hop mosaic virus and hop latent virus. Can. J. Microbiol. 22:1160-1162.

149. Probasco, E. G., and Skotland, C. B. 1976. Host range and properties of the third rodshaped virus found in hops. Proc. Am. Phytopathol. Soc. 3:319.

150. Probasco, E. G., and Skotland, C. B. 1978 Host range, general properties, purification and electron microscopy of hop latent virus. Phytopathology 68:277-281.

151. Puchta, H., Ramm, K., and Sänger, H. L. 1988. The molecular structure of hop latent viroid (HLV), a new viroid occurring worldwide in hops. Nucleic Acids Res. 16:41974216.

152. Puchta, H., Ramm, K., and Sanger, H. L. 1989. Hop latent viroid (HLVd), a new viroid occurring worldwide in hops. Pages 181-191 in: Proc. Int. Workshop Hop Virus Dis. Giessen.

153. Rohloff, H. 1989. ILAR-viruses in German hops. Pages 89-92 in: Proc. Int. Workshop Hop Virus Dis. Giessen.

154. Royle, D. J. 1978. Powdery mildew of the Hop. Pages 381-409 in: The Powdery Mildews. D. M. Spencer, ed. Academic Press, London.

155. Royle, D. J., and Kremheller, H. T. 1981 Downy mildew of the hop. Pages 395-419 in: The Downy Mildews. D. M. Spencer, ed. Academic Press, New York.

156. Salmon, E. S. 1923. The mosaic disease of the hop. J. Ministry Agric. 29:1-7.

157. Salmon, E. S., and Ware, W. M. 1930. Nettlehead disease of the hop. J. South Eastern Ag ric. Coll. 27:95.

158. Salmon, E. S., and Ware, W. M. 1930. The chlorotic disease of the hop. Ann. Appl. Biol. $17: 241-247$

159. Sano, T. 2003. Hop stunt viroid. Pages $207-$ 212 in: Viroids. A. Hadidi, R. Flores, J. W. Randles, and J. S. Semancik, eds. CSIRO Publishing, Collingwood, Australia.

160. Sano, T., and Shikata, E. 1989. Hop stunt disease. Pages 159-164 in: Proc. Int. Workshop Hop Virus Dis. Giessen.

161. Sano, T., Yoshida, H., Goshono, M., Monma, 
T., Kawasaki, H., and Ishizaki, K. 2004. Characterization of a new viroid strain from hops: Evidence for viroid speciation by isolation in different host species. J. Gen. Plant Pathol. 70:181-187.

162. Sasaki, M., Fukamizu, K., Yamamoto, K., Ozawa, T., Kurokawa, M., and Kagami, Y. 1989. Epidemiology and control of hop stunt disease. Pages 165-178 in: Proc. Int. Workshop Hop Virus Dis. Giessen.

163. Sasaki, M., and Shikata, E. 1977. On some properties of hop stunt disease agent, a viroid. Proc. Jpn. Acad. Ser. B. 53:109-112.

164. Sasaki, M., and Shikata, E. 1980. Hop stunt disease, a new viroid disease occurring in Japan. Rev. Plant Protn. Res. 13:97-109.

165. Schmidt, H. E. 1967. New results of hop virus research. Pages 47-53 in: Proc. Conf. Czechoslovak Plant Virologists, 6th.

166. Schmidt, H. E., and Karl, E. 1967. Untersuchungen uber eine Scheckung am Japanischem Hopfen [Humulus scandens (Lour.) Merr.]. Phytopathol. Z. 56:272-278.

167. Schmidt, H. E., and Klinkowsi, M. 1965. Virosen des hopfens in Europa. Phytopathol. Z. 54:122-146.

168. Schmidt, H. E., Schmidt, H. B., and Eisbein, K. 1966. Die mechanische übertragung eines stäbschenformingen hopfenvirus auf krautige testpflanzen. Zentbl. Bakt. ParasitKole (Abt II) $120: 461-466$

169. Scott, S. W., and Zimmerman, M. T. 2006. The complete sequence of the genome of Humulus japonicus latent virus. Arch. Virol. 151:1683-1687.

170. Sharpe, F. R., and Laws, D. R. J. 1981. The essential oil of hops: A review. J. Inst. Brew. 87:96-107.

171. Skotland, C. B. 1989. Epidemiology of hop viruses in the U.S.A. Pages 13-18 in: Proc. Int. Workshop Hop Virus Dis. Giessen.

172. Small, E. 1978. A numerical and nomenclatural analysis of a morphogeographic taxa of Humulus. Syst. Bot. 3:37-76.

173. Smith, K. M., Dunez, J., Lelliot, R. A., Phillips, D. H., and Archer, S. A., eds. 1988. European Handbook of Plant Diseases. Blackwell Scientific Publications, Oxford.

174. Smith, D. R., and Skotland, C. B. 1986. Host range and serology of Prunus necrotic ringspot virus serotypes isolated from hops $(\mathrm{Hu}$ mulus lupulus) in Washington. Plant Dis. 70:1019-1023.

175. Solarksa, E., Skomra, U., Kitlinksa, J., and Wojcierowski, J. 1995. The occurrence of hop latent viroid (HLVd) in hop plants in Poland. Phytopathol. Polonica 10:55-59.
176. Takahashi, T. 1979. Diagnosis and control of hop stunt disease. Agric. Hortic. 54:10311034.

177. Takashashi, T., and Yaguchi, S. 1985. Strategies for preventing mechanical transmission of hop stunt viroid: Chemical and heat inactivation on contaminated tools. Z. Pflanzenkr. Pflanzenschutz 92:132-137.

178. Taylor, C. E. 1978. Plant-parasitic Dorylaimida: Biology and virus transmission. Pages 232-243 in: Plant Nematology. J. F. Southey, ed. ADAS MAFF 1978

179. Taylor, C. E., and Thomas, P. R. 1968. The association of Xiphinema diversicaudatum Micoletzky with strawberry latent ringspot and arabis mosaic viruses in a raspberry plantation. Ann. Appl. Biol. 62:147-157.

180. Thresh, J. M. 1969. Hop latent virus. Rep. East Malling Res. Stn. 1968:41.

181. Thresh, J. M. 1981. Virus diseases of hop. Rep. East Malling Res. Stn. 1980:85-86.

182. Thresh, J. M., and Adams, A. N. 1983. Hop mosaic disease. Rep. East Malling Res. Stn. 1982:173-175.

183. Thresh, J. M., Barbara, D. J., and Ormerod, P. J. 1989. The incidence and spread of prunus necrotic ringspot virus in English hop plantings. Pages 71-82 in: Proc. Int. Workshop Hop Virus Dis. Giessen.

184. Thresh, J. M., and Edwards, P. 1983. Virus and virus diseases of hop - Arabis mosaic virus (AMV). Rep. East Malling Res. Stn. 1982:89.

185. Thresh, J. M., and Ormerod, P. J. 1973. Virus diseases of hop - Spread of prunus necrotic ringspot virus in hop. Rep. East Malling Res. Stn. 1972:163-164.

186. Thresh, J. M., and Ormerod, P. J. 1974. Problems caused by wild and regenerating hop plants. Pages 323-331 in: Proc. Br. Weed Control Conf. 12th.

187. Thresh, J. M., and Ormerod, P. J. 1976. Virus diseases of hop. Rep. East Malling Res. Stn. 1975:122-123.

188. Thresh, J. M., and Ormerod, P. J. 1989. Arabis mosaic virus in English hop plantings. Pages 43-54 in: Proc. Int. Workshop Hop Virus Dis. Giessen.

189. Thresh, J. M., and Pitcher, R. S. 1978. The spread of nettlehead and related virus diseases of hop. Pages 291-298 in: Plant Disease Epidemiology. P. R. Scott and A. Bainbridge, eds. Blackwell Scientific Publications, Oxford.

190. Thresh, J. M., Pitcher, R. S., McNamara, D. G., and Ormerod, P. J. 1972. The spread and control of nettlehead and related diseases of hop. Rep. East Malling Res. Stn. 1971:155 162

191. Thompson, F. C., and Neve, R. A. 1971. The effects of arabis mosaic virus on yield and $\alpha$ acid content of the variety Bullion. Ann. Rep. Wye Coll. Dep. Hop Res. 1970:47-49.

192. Trudgill, D. L., Brown, D. F. J., and McNamara, D. G. 1983. Methods and criteria for assessing the transmission of plant viruses by Longidorid nematodes. Rev. Nematol. 6:133 141

193. Valdez, R. B., McNamara, D. G., Ormerod, P J., Pitcher, R. S., and Thresh, J. M. 1974. Transmission of the hop strain of arabis mosaic virus by Xiphinema diversicaudatum Ann. Appl. Biol. 76:113-122.

194. Verzele, M. 1986. Centenary review: 100 years of hop chemistry and its relevance to brewing. J. Inst. Brew. 86:9-14.

195. Vine, S. J., and Jones, O. P. 1969. The culture of shoot tips of hop (Humulus lupulus L.) to eliminate viruses. J. Hortic. Sci. 44:281-284.

196. Von Weschmar, W. B., Brits, G., and Coleman, T. 1989. Viruses in hops and aspects of virus epidemiology and hop production in South Africa at $34^{\circ}$ southern latitude. Pages 33-42 in: Proc. Int. Workshop Hop Virus Dis. Giessen.

197. Wade, G. C. 1962 . Hop diseases in Tasmania Tas. J. Agric. 7:261-268.

198. Wetzel, T., Fuchs, M., Bobko, M., and Krczal, G. 2002. Size and sequence variability of the Arabis mosaic virus protein 2A. Arch. Virol 147:1643-1653.

199. Wilson, C. R., Pethybridge, S. J., Hay, F. S., and Crowle, D. R. 2004. Epidemiology and significance of viruses affecting hop (Humulus lupulus L.) and the implications for disease management. Pages 99-123 in: Recent Research Developments in Plant Pathology, vol. 3. S. G. Pandalai, ed. Research Signposts, Kerala, India.

200. Xie, H., and Tian, B. 1984. A strain of tobacco mosaic virus infecting hops in the Xinjiang province. Page 7 in: Sympos. Viruses Agric. China. Cited by Yu and Liu (1987)

201. Yamamoto, H., Kagami, Y., Kurokawa, M., Nishimura, S., Ukawa, S., and Kubo, S. 1973. Studies on hop stunt disease in Japan. Rep. Res. Lab. Kirin Brewery Co., Ltd. 16:49-62.

202. Yu, J., and Liu, Y. 1987. The occurrence of three viruses in hop (Humulus lupulus L.) in China. Plant Pathol. 36:38-44.

203. Zielinska, L., and Micinkski, B. 1983. Ultrastructure of cells of hop leaves displaying symptoms of hop infectious sterility. Rev Plant Pathol. 64:66. 